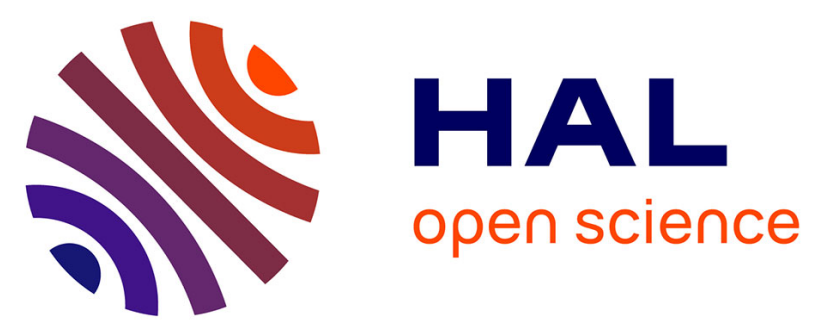

\title{
The challenge of gene therapy for neurological diseases: strategies and tools to achieve efficient delivery to the central nervous system
}

Timothée de Saint Denis, Françoise Piguet, Emilie Audouard, Kevin Beccaria, Arthur André, Guillaume Wurtz, Raphael Schatz, Sandro Alves, Caroline Sevin, Michel Zerah, et al.

\section{To cite this version:}

Timothée de Saint Denis, Françoise Piguet, Emilie Audouard, Kevin Beccaria, Arthur André, et al.. The challenge of gene therapy for neurological diseases: strategies and tools to achieve efficient delivery to the central nervous system. Human Gene Therapy, 2021, 32 (7-8), pp.349-374. 10.1089/hum.2020.105 . hal-03265982

\section{HAL Id: hal-03265982 \\ https://hal.sorbonne-universite.fr/hal-03265982}

Submitted on 21 Jun 2021

HAL is a multi-disciplinary open access archive for the deposit and dissemination of scientific research documents, whether they are published or not. The documents may come from teaching and research institutions in France or abroad, or from public or private research centers.
L'archive ouverte pluridisciplinaire HAL, est destinée au dépôt et à la diffusion de documents scientifiques de niveau recherche, publiés ou non, émanant des établissements d'enseignement et de recherche français ou étrangers, des laboratoires publics ou privés. 
2 The challenge of gene therapy for neurological diseases: strategies and tools to achieve

3 efficient delivery to the central nervous system

4

Françoise Piguet ${ }^{1 \#^{*}}$, Timothée de Saint Denis ${ }^{1,2 \#}$, Emilie Audouard ${ }^{1}$; Kevin Beccaria ${ }^{1,2}$, Arthur André ${ }^{1,3}$, Guillaume Wurtz ${ }^{1}$, Raphael Schatz ${ }^{1}$, Sandro Alves ${ }^{4}$, Caroline Sevin ${ }^{1,4}$, Michel Zerah $^{1,2 \#^{*}}$ and Nathalie Cartier ${ }^{1 \#^{*}}$

\section{Authors affiliations}

1 NeuroGenCell, INSERM U1127, Paris Brain Institute (ICM), Sorbonne University, CNRS, APHP, University Hospital Pitié-Salpêtrière, Paris, France.

2 APHP, Department of Pediatric Neurosurgery, Hôpital Necker-Enfants Malades, APHP Centre. Université de Paris

3 APHP, Department of Neurosurgery, Hôpitaux Universitaires La Pitié-Salpêtrière, Sorbonne Universités, UPMC Univ Paris 6, Paris, France

4 Brainvectis Therapeutics, iPeps Paris Brain Institute, Paris, France

5 APHP, Department of Neurology, Hopital le Kremlin Bicetre, Kremlin Bicetre, France.

\# These authors equally contributed to the work

*Corresponding authors:

Françoise Piguet francoise.piguet@icm-institute.org

Michel Zerah michel.zerah@aphp.fr

Nathalie Cartier nathalie.cartier@inserm.fr

\section{Abstract}

For more than ten years, gene therapy for neurological diseases has experienced intensive research growth and more recently therapeutic interventions for multiple indicationsBeneficial results in several phase $1 / 2$ clinical studies, together with improved vector technology have advanced gene therapy for the central nervous system (CNS) in a new era of development. While most initial strategies have focused on orphan genetic diseases, such as lysosomal storage diseases, more complex and widespread conditions like Alzheimer's disease, Parkinson's disease, epilepsy or chronic pain are increasingly targeted for gene 
1 therapy. Increasing numbers of applications and patients to be treated will require improving and simplifying gene therapy protocols to make them accessible to the largest number of affected people. While vectors and manufacturing are a major field of academic research and industrial development, there is a growing need to improve, standardize and simplify delivery methods. Delivery is the major issue for CNS therapies in general, and particularly for gene therapy. The blood brain barrier restricts the passage of vectors; and strategies to bypass this obstacle are a central focus of research. Here, we present the different ways that can be used to deliver gene therapy products to the CNS. We focus on results obtained in large animals that have allowed the transfer of protocols to human patients and have resulted in the generation of clinical data. We discuss the different routes of administration, their advantages and their limitations. We describe techniques, equipment and protocols and how they should be selected for safe delivery and improved efficiency for the next generation of gene therapy trials for CNS diseases.

\section{Introduction}

The central nervous system (CNS) is protectected by a unique microvasculature, the blood-brain-barrier (BBB), composed of endothelial cells connected by tight junctions and adherent processes. The BBB controls brain homeostasis as well as ion and molecule movements thus protecting the CNS against potential intruders. The restrictive nature of the BBB provides an obstacle for drug delivery to the CNS, and major efforts have been made to generate methods to modulate or bypass the BBB for delivery of therapeutics. Contrarily, some pathologies of the CNS including stroke, multiple sclerosis, brain traumas and neurodegenerative disorders, alter the BBB causing it to become more permeable, allowing the entry of molecules that can induce inflammatory responses and lead to neuronal damage ${ }^{1,2}$.

Gene therapy has been applied to several CNS diseases, including neurodegenerative ${ }^{3}$ and neurodevelopmental disorders ${ }^{4,5}$, but also increasingly for diverse conditions such as epilepsy $^{6}$, glioblastoma ${ }^{7}$ and pain ${ }^{8}$. Increasingly, gene therapy products can be tailored to counter the pathophysiological mechanisms of particular disease mechanism, including the use of gene replacement ${ }^{9-11}{ }^{-12,13}$, gene silencing ${ }^{14}$, transplicing ${ }^{15}$, modulation of cellular pathways to improve phenotype $\mathrm{e}^{16-19}$ or expression of suicide gene ${ }^{20}$. 
Gene therapy products can be delivered by various routes of administration, using either ex vivo or in vivo strategies. Ex vivo gene therapy involves autologous transplantation of hematopoietic stem cells corrected by genetic modification of lentivirus (HSC-GT) outside the body and subsequent transplantation of the cells back into the patient. HSC-GT has shown Efficacy for HCS-GT has been shown in clinical trials for leukodystrophies (ALD, MLD) 21,22 . Therapeutic action involves either production of the therapeutic protein by donor derived cells that can migrate into the CNS (permanent source of the missing enzyme), and/or modulation of the immune environment (replacement of microglial cells and/or perivascular macrophages). In vivo gene therapy requires direct introduction of the vector (carrying the therapeutic gene) into the patient (Figure 1). Intravenous administration is a common route of administration for in vivo gene therapy but for CNS diseases the the limited capacity of gene delivery systems to cross the BBB remains a significant obstacle Strategies such as disruption of the BBB integrity (by osmotic or biochemical means) or improvement of viral vector capsids continue to be developed toto enhance peripheral administration. Direct delivery into the parenchyma of the brain or the cerebrospinal fluid (CSF) bypasses the BBB and permits more targeted gene delivery. Following intrathecal or intracerebroventricular administration, the therapeutic vector enters the cerebrospinal fluid and is delivered throughout the CNS (at least to tissue adjacent to CSF spaces). Following intraparenchymal administration, the therapeutic vector enters the brain parenchyma and is delivered locally into brain cells. The diffusion of the therapeutic product is limited around the injection site;

21 however, secretion-uptake may improve diffusion, notably the case for most lysosomal storage disease enzymes.

The vector of choice for in vivo CNS delivery is the adeno-associated viral (AAV) vector. Recombinant AAVs have been widely used for CNS gene therapy, demonstrating safety, stable and long-term expression and some degree of neuronal tropism relevant for many therapeutic applications. A large body of preclinical results have been obtained, particularly in large animals like dogs, cats and non-human primates that have demonstrated feasibility for clinical $u^{23} e^{23}$.

Wild-type AAVs are non-enveloped parvovirus, which are characterized by an 30 icosahedral capsid and a $4.7 \mathrm{~kb}$ single stranded DNA genome. To complete a replication cycle, 31 AAVs require coinfection by a helper virus like adenovirus or herpes virus. AAVs infect humans and other species including the non-human primate (NHP) ${ }^{24}$. Natural infection with AAV is not 
1 known to lead to disease, although there is controversy concerning hepatocellular

2 carcinoma ${ }^{25,26}$. The minimal sequence needed to generate Recombinant $A A V s$ is restricted to 3 the $145 \mathrm{bp}$ within the inverted terminal repeats (ITRs) flanking the transgene ${ }^{27}$. The overall 4 capacity of AAV to package an ITR-flanked genome productively is the approximate size of the wild-type AAV genome (i.e., $4.7 \mathrm{~kb}$ ).

Overall AAV vectors have been used and have proven their safety and low immunogenicity tolerance in more than 200 human studies ${ }^{28}$. Efficiency of an AAV administration is determined mainly by the capsid, that directs the tropism of the virion, but can be impacted by the route of administration ${ }^{29}$. It is also well established that the specificity of transgene expression is dependent on both the capsid and the regulatory elements present in the vector $^{30}$. There are a large number of AAV serotypes based on capsid structure ${ }^{31}$. AAV2, the first AAV serotype to be used as a replication-defective vector, has been the most extensively characterized. Other AAV serotypes developed later as vectors, employ a cross-packaging system, in which genomes flanked by AAV2 ITRs are packaged in other AAV capsids. These serotypes have a wide variety of tissue and cell tropism ${ }^{32}$. For gene transfer to the CNS the most frequently used capsids have been AAV1 ${ }^{33}, \mathrm{AAV}^{34-36}, \mathrm{AAV} 5^{37}, \mathrm{AAV} 9^{12}$ and AAVrh. $10^{9,38}$. AAV9 was shown to naturally cross the BBB and allowing for widespread, but limitedexpression of therapeutic genes in the CNS after a single intravenous injection of vector $^{39,40}$. Importantly, the first clinical report of gene-replacement therapy for SMA type I has demonstrated the safety and efficacy of this approach ${ }^{41}$. However, the efficacy of brain transduction efficacy may vary with the patient age at treatment. Ongoing efforts to engineer capsids with improved capacity to cross the BBB. AAV variants ${ }^{42,43}$ such as AAV.PHP.B and $\mathrm{AAV}-\mathrm{B} 1^{41,44}$ have resulted in superior capacity for CNS targeting, at least in the animal models tested $^{45}$. Lentiviral vectors (LV) are members of the Retroviridae family, and based either on human immunodeficiency virus (HIV), non-primate primates (SIV), or others such as equine infectious anemia virus $(E I A V)^{46}$. The viral genome contains two long terminal repeats (LTR), with elements required for gene expression, reverse transcription and integration into host chromosome ${ }^{47}$. For safety and efficacy, third generation of LVs do not have viral genes. Gag,

30 Pol and Rev genes are present in the packaging construct that allow the production of the 31 recombinant vector but not in the transgene construct. Different pseudotypes of LV with different envelopes allowing for different viral tropism have been developed. The most 
1 frequently used is the vesicular stomatitis virus glycoprotein (VSV-G), which has a broad

2 tropism in vitro and neuronal and glial tropism in vivo ${ }^{48,49}$. Lentiviruses are able to penetrate

3 the intact nuclear membrane through nuclear pores, do not require cell division and can

4 efficiently infect quiescent cells ${ }^{50,51}$. This ability to transduce dividing and non-dividing cells, long-term stable expression through transgene integration into the chromosomes of host cells, and their large cloning capacity make LVs desirable vectors for gene therapy ${ }^{52}$. They also have a cloning capacity of $9.7 \mathrm{~kb}$.

LVs are particularly useful for ex vivo gene therapy applications. Hematopoietic stem cells (HSCs) can be stably transduced using lentiviral vectors; allowing for stable, indefinitely persisting expression within the host cell, despite repeated cell division. This characteristic has been widely applied to CNS lysosomal storage diseases or Adrenoleukodystrophy ${ }^{53,54}$. Random integration in the genome of host cells is associated with a potential genotoxicity risk, as previously observed with retroviruses ${ }^{55,56}$. However, long-term follow-up of gene therapy trials has not identified adverse events associated with insertional mutagenesis ${ }^{57-59}$. In vivo use of lentivectors for CNS applications has been more limited. Because of their capacity to transduce neurons, they have been tested for the treatment of Alzheimer's disease (AD) and Parkinson's disease (PD ${ }^{60-62}$. For this review, we focused more on AAV since they have been more widely used in CNS targeting for large animals and human clinical trials.

\section{Evaluation of administration routes in preclinical studies}

Translation to clinical application after proof-of-concept in mouse models of the disease most often requires efficacy and tolerance studies in large animals.

Many species have been used ${ }^{63}$ for preclinical development. Affinity for the different types of brain cell in large animal species remains a major isssue. The choice of the large animal model to be used is mainly based on the use of a large animal model of the disease when available ${ }^{64-67}$ otherwise on anatomical aspect to mimic the best situation to be reproduced for future clinical trials.

When the gene therapy product is administered by injection in the blood stream or the CSF any suitable species of large animal can be employed. However, when delivery is based on direct intra-parenchymal injection into the brain for characterizing biodistribution, toxicity,

31 diffusion, affinity with different types of brain cells, pigs, sheep and non-human primates (NHP) are preferred species for modeling trajectories and efficient targeting. In all cases it 
1 must be emphasized that the use of large animals is strictly limited for ethical reasons and should be performed in GLP or GLP-like conditions to be usable for regulatory documents.

Intraparenchymal delivery

The principle studies of intra-parenchymal (IP) gene delivery in large animals are summarized in Table 1. Direct IP injection - either direct perfusion or convection enhanced delivery (CED)- allows targeted delivery in CNS regions while bypassing the BBB. However, IP injections remain more complex to perform than ICV or IT techniques for several reasons ${ }^{69}$. The choice of the target region is always a challenging balance between efficacy and safety. Therefore, the specific anatomy as well as pathophysiology of the disease should be considered when choosing target sites.. Targeting the white matter in multiple sites may enhance vector spreading ${ }^{11}$. In particular, AAV vectors are readily transported along axons which facilitate the distribution of the therapeutic gene ${ }^{70}$. The spreading and directionality of AAV transport are serotype-dependent ${ }^{71}$. AAV2, which has been widely used in IP gene delivery, resulted in anterograde transport ${ }^{72}$ of vector particles from basal ganglia to cortex in $\mathrm{NHP}^{73,74}$. In contrast, AAV6 is axonally transported exclusively in a retrograde direction ${ }^{72}$ while AAV9 shows a bidirectional transport and is dose dependent ${ }^{75}$.

Recent studies suggest that AAV5 and AAvrh10 have more global transduction with widespread distribution in the brain $\mathrm{n}^{11,76,77}$ and spinal cord. Lentiviral vectors are able to deliver the therapeutic gene in a restricted area ${ }^{78,79}$.

Intracerebrospinal fluid delivery

As an alternative to intraparenchymal delivery and to target larger brain or spinal cord volumes, especially in neurodegenerative diseases involving widespread regions, an alternative to intraparenchymal injection is intra-CSF delivery.

For this purpose, three major routes can be used: intracerebroventricular delivery into the ventricles, the cisterna magna as widely used in large animal models (Table 1) or by intrathecal delivery into the CSF surrounding the spinal cord (Table 2).

Lentiviral vectors have been used in one approach in adult sheep, but this reported attempt resulted in very limited transduction close to the needle track with up to $2.5 \mathrm{~mm}$

31 rostro-caudal transduction ${ }^{80}$. AAVs lead to greater transduction especially in adults. ICV delivery in young animals differ, providing extensive transduction of motorneurons in some 
1 cases. Using scAAV9 in 5-days old pigs ${ }^{81}$ and in 10-11 days old dog, Katz et al. reported a TPP1 activity increase in CSF a few days after transduction, but then loss of the transgene due to immune response against the transgene product ${ }^{82}$. AAV9 and AAVrh10 have been predominantly injected with doses ranging from $10^{12} \mathrm{vg}$ to $5.10^{13} \mathrm{vg}$ in dogs, NHP and cat ${ }^{70,83-}$ 91 mainly in the cisterna magna with either GFP or therapeutic genes (Table 2). Diffuse transgene expression was obtained in the cortex and cerebellum (Table 2). In most studies, efficacy of spinal cord targeting was not analyzed; however, available studies report highly variable results with large motoneuron transduction ${ }^{92}$.

As an alternative to ICV delivery or depending on the pathology to improve spinal cord targeting, delivery in the CSF can be achieved through intrathecal injection. Studies have been performed in $\operatorname{dog} s^{89,93,94}, \mathrm{NHP}^{13,88,95}$, pigs $^{87,96}$ and marmosets ${ }^{97}$ mainly using AAV9 or AAVrh10 vector in neonates ( 5 day-old) to adult animals (Table 3 ). Two major techniques are routinely used for intrathecal delivery, either a single delivery without the use of a catheter, generally performed in the L4/L5 space, or with prior insertion of a catheter to allow either single or multiple deliveries ${ }^{87,98}$. Intrathecal delivery leads to efficient motoneurons transduction with efficiency ranging from $10-30 \%^{87}$ to $80 \%^{13}$ depending on the study (Table 3 ), but sparse transduction in the brain (Table 3). Two studies have evaluated placing the animal in the Tredelenburg position with the feet elevated above the level of the head to improve the upward diffusion of the vector. Variable results were reported, one showing no improvement ${ }^{99}$ and the other one a slight increase, with up to 55\% targeting of cervical motoneurons ${ }^{13}$ (Table 3).

Even if ICV delivery is designed to target basal ganglia (Figure 1d), intracisternally to target the cortex (Figure 1c) and intrathecal delivery for the spinal cord (Figure 1b), the direct relationship between the site of injection and the efficient delivery to the target has never been proven, and appear to different between NHP and human in relation to the volume of the respective brains and the distance between CSF pathways and the CNS targets.

In between intraparenchymal and intra-CSF delivery, for intraspinal targets, spinal subpial delivery has been proposed in mice, rats and pigs ${ }^{100,101}$. Despite the short distances for spinal diseases, the primary issues remain the need for an open micro-neurosurgical approach following laminectomy (or a laminotomy) and the risk of neurological deficits secondary to spinal cord subpial bleeding. 
As an alternative to more invasive injections, IV delivery has recently become an option to target the CNS, especially with the SMN trial ${ }^{41}$. AAV9 and AAVrh10 are once again the major serotypes injected dosing from $10^{12} \mathrm{vg} / \mathrm{kg}$ up to $10^{14} \mathrm{vg} / \mathrm{kg}$. In neonates ( 2 to 7 days-old) studies have demonstrated up to $39 \%$ transduced motoneurons in cats ${ }^{81}$ but other studies were unable to detect the transgene ${ }^{92}$ (Table 4). In adults differ with mild to no neuronal transduction ${ }^{85,94}$ either in spinal cord and brain (Table 4). Transduction was in any case much lower compared to ICV ${ }^{88}$ or intrathecal delivery and glial cells were predominantly transduced 90,96, without clear explanation.. In addition, IV delivery led to an significant transduction of peripheral organs (Table 4).

\section{Routes of administration in clinical studies}

While intravenous delivery is readily transferred from animal models to human trial conditions, CSF or brain delivery techniques must be carefully adapted for human conditions (brain anatomy and volumes). ICV, cisternal and intrathecal methods, can however all be used in human subjects. There is very little intraventricular vector diffusion after cisternal or intrathecal injection; most of the product remains in the spinal compartment or reaches the peri-cerebral space. Because of the size of the brain and the distance between the ventricles and the cortex, it is impossible to achieve consequent and homogenous diffusion by any CSF route.

21 Intraparenchymal injection is possible in the human brain, in deep nuclei, or in the white 22 matter (but may need multiple simultaneous injections to obtain sufficient diffusion), but there is no reliable technique for delivering to the spinal cord parenchyma.

The doses of vector delivered depends on the route of administration. While intraparenchymal delivery requires small amounts of vector ranging from $10^{9}$ to $2.5 .10^{12}$ total vg in NHP and human, doses from $10^{12}$ to $5.10^{13}$ vg are required for ICV or intrathecal delivery. Intravenous delivery dramatically increases the number of particles required; from $5.10^{12}$ to $510^{14} \mathrm{vg}\left(10^{12}\right.$ to $\left.10^{14} \mathrm{vg} / \mathrm{kg}\right)$ in NHP and close to $10^{15} \mathrm{vg}$ in patients in the SMA trial $\left(2.10^{14} / \mathrm{kg}\right)$ (see tables 1-6).

30 Local administration of low doses of vector limits biodistribution and the risk of 31 immunogenicity or toxicity due to AAV capsid or expression of the transgene. The high doses 
1 required for intra-CSF and IV administration raise issues of immunogenicity, manufacturability 2 and final cost.

Translating gene therapy proof of concept in animal models to clinical application in patients requires adapting delivery protocols. Translation may be simple for intra-CSF or IV delivery, based on the weight of the animal or the volume of the brain tissue or of the CSF. Modeling the delivery into the brain parenchyma is more critical for designing a clinical protocol. This should take into consideration the volume of the target region determined by imaging, the sites and the number of injections, the degree of anatomical precision required, the volumes to be injected, and the flow (constant or CED). Translating these parameters from large animal brain to human brain requires specific anatomical adaptations (needle track in particular) and evaluation of feasibility, safety and efficiency in terms of biodistribution in animal models under conditions as close as possible to the human clinical procedure.

There is no limits for age, and theoretically, it is possible to treat even newborns by all routes of delivery. It is possible to use frameless stereotactic delivery using magnetic or optic neuronavigation. In addition, robotic systems are now available even in the youngest subjects. The youngest child treated by our team with intracerebral delivery (16 targets supra and infratentorial) was 9 month-old 9 .

Intra cerebro-spinal fluid delivery

To overcome the inability of the gene therapy vectors to cross the BBB, direct injection within the CNS compartment has been attempted ${ }^{102}$. All trials using these routes of administration are summarized in Table 5. Three main modalities can be discussed:

- Intrathecal lumbar administration with 2 potential modalities:

(1) Direct unique injection by a lumbar tap or through an intraspinal catheter connected to a subcutaneous reservoir. The use of a single injection by lumbar tapping is a non-surgical procedure. It could be done, in a medical environment, with local anesthesia. In difficult cases, the use of Fluoroscopy or Ultrasonography ${ }^{68}$ can facilitate the procedure (or to guide a catheter insertion). The main inconvenience of this techniqueis the risk of CSF leak in the extradural space at the moment of needle removal and the one to two days post procedure. Consequently, it is impossible to precisely control the quantity of vector 
administered within the intradural space. The use of atraumatic G22 needle (Sprotte) can minimize this risk ${ }^{68}$.

(2) To avoid this major inconvenience, the alternative is to install a subcutaneous reservoir connected to an intraspinal catheter ${ }^{68}$. This procedure must be done in the operative room, under general anesthesia. Injection must be performed one or two weeks after the initial surgery and the removal of the system at least one week after. This technic guaranties control of the injected volume, but needs two general anesthesias and increases the risk of infection. The main incertitudes of this technique is determiningthe exact distribution of the product between the different compartments; intraspinal CSF, intraventricular and intracranial subarachnoidal spaces (Figure 1). The main disadvantage of the ITL access results from the natural flow of CSF from the intraventricular choroid plexus to the subarachnoid space around the spinal cord and finally to the pericerebral spaces for resorption through the venous system. Reaching the brain target through the CSF stream requires a large dose volume. Other associated strategies can be used to improve the efficacy such as a buffer flush or a Tredelenburg position. Complications due to the device and its implantation also have to be considered. Meningitis can be a severe infectious complication that needs removal of the system and adapted antibiotics treatment. Other mechanical complication can be encountered such as migration, rupture or disconnection, kinked or obstructed catheter. A CSF leak around the catheter to the subcutaneous space can lead to an artificial meningocele that can impair the ability to infuse the treatment. To overcome this problem, two other modes of administration have been proposed.

- Intracisternal administration ${ }^{103,104}$.

In most cases, it is possible to inject within the cisterna magna at the level of the craniovertebral junction. Even if it is possible to do it while the patient is awake, general anesthesia will be preferred, especially in the pediatric population. The risk of leakage is very low through this route and in most cases the reservoir is useless.

- Intraventricular administration

A third way route to the CSF space is to inject directly within the cerebral ventricles. In most cases, it will be done in the frontal horn by direct puncture under stereotactic guidance or more frequently now under frameless neuronavigation. In adults, it is 
easily doable under local anesthesia and light sedation, in the pediatric population general anesthesia is preferavble. Installation of an intraventricular catheter connected to a reservoir amy be preferred, however for a single injection, direct injection is safe and efficient. It is also better for controlling the volume of injection and its distribution. However, because of the risk of parenchymal bleeding, most authors prefer the cisternal approach.

\section{Intraparenchymal delivery}

Few human trials using the intracerebral route are reported (Table 6); Both in adults (Huntington, Parkinson and Alzheimer diseases) and children (SMA, Canavan, Batten, mucopolysaccharidosis, MLD). The vast majority of the trials have employed AAV vectors (from $10^{7}$ to $10^{13} \mathrm{vg}$ ) with injections in the deep grey nuclei or in the white matter (only for metabolic diseases in children). Most published trials are Phase $1 / 2$ and one is phase 3 . Several studies obtained romising results even if partial or preliminary. Importantly, few severe adverse events have been reported.

\section{Technical aspects: state of the art}

Regarding delivery technique, we focus here on intracerebral delivery, indeed, other routes of delivery have been largely described previously and have not been researched as intensively.

\section{Devices for intraparenchymal delivery of therapeutics agents}

Intraparenchymal drug delivery systems offer a practical method for bypassing the BBB to deliver gene therapy. Direct access to parenchyma allows delivery at doses and concentrations that would otherwise correspond to very high levels and volumes systemically. However, this method still has constraints and limitations. For more than ten years, considerable research has focused on developing methods to enhance drug delivery ${ }^{105}$, through dedicated intraparenchymal devices.

Principles: Intraparenchymal delivery has two principle challenges : minimize backflow along the injection device and promote optimal drug distribution ${ }^{106}$, often in a spherical tissue volume. The distribution volume depends on infusion flow rate, infusion volume and number of injection sites and the type of vector that is injected ${ }^{107}$. The occurrence of backflow depends on several variables including cannula radius, infuse flow rate, and tip location ${ }^{108}$. Indeed, 
1 many parameters influence the safety and efficiency of infusion: infusion flow rate, cannula 2 size, infusion volume, and drug molecular size/charge ${ }^{109}$. Variations in flow rate impact the 3 location of infusate distribution. Lower infusion rates (under $1 \mu \mathrm{l} / \mathrm{min}$ ) are associated with distribution localized primarily to the target tissue (they are used for focal injection in specific areas, mainly in grey matter nuclei) whereas higher infusion rates result in increased distribution into the surrounding parenchyma («overflow»)106,109. Several techniques have been proposed to increase infusion rates (up to $10 \mu \mathrm{l} / \mathrm{min}$ ); among them the use of CED ${ }^{110}$ (convection enhanced delivery) which appears to provide the best compromise for extensive diffusion with minimal local damage. They are used combined with multiple injections (up to 16) ${ }^{9}$ when the whole brain must be treated (lysosomal diseases) ${ }^{11}$. Increases in infusion rates raise the local pressure around the infusion site and also increases the extent of backflow. Cannula size seems to have no effect on distribution; however, larger cannulas cause more tissue damages and therefore produce decreased resistance pathways along the brain parenchyma-catheter interface that are associated with increased rates of backflow ${ }^{109}$.

Catheters subtypes: Three kind of delivery devices can be distinguished : catheters derived from another use (especially intraventricular devices), «homemade» designed catheters ${ }^{11,38,105,111}$ from teams experimenting with pre-clinical intracerebral drug delivery or for early clinical studies ${ }^{38}$, and more recently commercialized catheter for specific intraparenchymal use (often developed from the homemade devices, and for intracerebral chemotherapy). Principal available devices are described in Table 7. Ventricular catheters (2-3 $\mathrm{mm}$ outer diameter) that have been implanted in clinical trials to treat glioma have failed to distribute effectively and have been linked to poor distributions ${ }^{112,113}$ Microcatheters (less than $1 \mathrm{~mm}$ outer diameter) seem more reliable, and all FDA approved catheters for CED belong to this category.

Design: Recent catheters have been designed to reach the goals of parenchyma delivery : minimize invasiveness through a minimal diameter tubing (Casanova), optimize infusion parameters to maximize distribution volume, and a reflux inhibiting feature is required to halt backflow along the catheter entry track ${ }^{112}$. All these characteristics are summarized in Table 7. Means to minimize backflow are the following : polymer-impregnated tips $^{105,114}$; stepped-design cannula ${ }^{108,115,116}$ Recessed-design cannula ${ }^{112,117}$ (Bristol). Means to enhance delivery are: multiporous cannula, multiport catheters, mobile-tip catheter, balloon- 
1 of the cannula with a stylet during insertion ${ }^{106}$. Another new advance is a multi-site delivery

2 catheter with one single tube ${ }^{118}(\mathrm{CMC}, \mathrm{IMI})$ that allows multiple targeting points and more

3 homogenous delivery in a three dimensional array.

4 Pumps and syringes: To enable injection of small volumes at precise, low speeds, specific pumps and syringes must be employed. For pumps, most are manufactured for research use (Harvard Apparatus, Holliston Massachusetts, USA), and special authorizations must be obtained for clinical use. Injection systems: Combining precision delivery and limited procedure time.

Classical stereotactic technics are well adapted for injection in a unique site of brain parenchyma - however, new techniques allowing multiple brain injections of the gene therapy for many indications are needed. Specific 3D MR sequences allow precisetargeting in white matter or in deep grey matter nuclei (striatum, thalamus, caudate nucleus...). Preplanning using neuronavigation software $\left(\right.$ Medtronic ${ }^{\circledR}$ or Brainlab $^{\circledR}$ ) facilitates the choice of trajectories, modeling delivery and rehearsingthe surgical procedure. Optic or magnetic neuronavigation system with or without robotic tools $\left(\operatorname{Rosa}^{\circledR}\right.$, $\operatorname{Renishaw}^{\circledR}, \operatorname{Medtronic}^{\circledR}$, Brainlab ${ }^{\circledR}$ ) allows frameless insertion of multiple cannulas, supra or infra-tentorially according to the preplanning. Altogether these systems allow the delivery of therapeutic product reproducibly with high precision (around $1 \mathrm{~mm}$ ). Intra-operative Real-time MRI has also been proposed as an additive tool to verify the position of the cannula and to check the diffusion of the product with simultaneous gadolinium injection ${ }^{119,120}$, albeit with the risk of long term 21 toxicity.

\section{Risks assessment}

\section{Linked to the delivery procedure}

Risks due to anesthesia are mainly correlated to the disease itself and related comorbidities. All injections or catheter placement can result in a CNS injury or hemorrhagic complications. Lumbar puncture is at very low risk of complication if done at the low lumbar level without spinal cord anomalies such as low tethered cord. Epidural hematoma can occur, especially with repeated punctures. Spinal epidural hematoma can remain asymptomatic but sometimes cause radicular pain and even rare motor impairment or sphincter dysfunction in case of cauda equina syndrome. A motor impairment requires a surgical evacuation. Lumbar 
1 puncture can cause subarachnoid bleeding leading to radiculitis, pain and headache. In case of spinal deformity, fluoroscopy or ultrasonography may help to guide the puncture. Intrathecal catheter placement needs the use of a guide wire to conduct the catheter to the thoracic level or higher and can result in a spinal cord injury and cause motor or sensitive (transient in the vast majority of the cases) dysfunction. The risk of a hemorrhagic complication in the epidural or intradural space is higher in relation to the larger size of the needle.

Intracranial hypotension symptoms can occur secondary to a lumbar puncture and cause severe orthostatic headaches which can be managed with supine position, painkillers and if needed, blood transfusion.

Intracisternal puncture requires an adequate cisternal space (verified by MRI), a motionless situation and an experienced operator. The size of the cisterna magna and the shape of the skull, a Chiari anomaly or a foramen magnum stenosis increase the risk of neurological complication (Bulbomedullary junction injury responsible for cardiorespiratory arrest).

Intraventricular access is performed through a right frontal of the brain. Bleeding can occur along the trajectory at each level: sub cutaneous hematoma or epidural hematoma are rare. Subdural hematoma can occur by direct bleeding or an intracranial hypotension secondary to a CSF loss, intraparenchymal hematoma can be asymptomatic but may, if extended, lead to motor or cognitive impairment. Intraventricular bleeding may be responsible for headaches and sometimes secondary hydrocephalus.

\section{Linked to the treatment}

24 Gene therapy using viral vectors is mainly hampered by immunogenicity ${ }^{121-125}$ particularly with AAV . Indeed, many people have already been infected by wild-type AAV once in their life, inducing anti-capsid neutralizing antibodies (NAb) spread among various serotypes ${ }^{126-129}$. Moreover, cross-reactive immunologic material (CRIM) status is also important to predict clinical response. CRIM-negative patients with null mutations or out of frame stop codons are completely unable to produce protein [that has to be supplied/involved in their disease] and are therefore more predisposed to develop an anti-transgene response ${ }^{130,131}$. Such host

31 immune responses, particularly happening when intravenous and intramuscular injections are performed, significantly impair delivery of the therapeutic protein and be possibly deleterious 
1 for patients ${ }^{132-134}$. Delivery of AAV vectors directly into the brain induce low or absentanti2 capsid or anti-transgene NAb titers in serum ${ }^{119,135-138}$. Thus, it must be considered for patient 3 inclusion criterias and study design in clinical trials. Conventional strategies to prevent 4 immunogenicity include corticosteroids or immunosuppressive drugs. Corticosteroids (e.g. methylprednisolone, prednisone) and immunosuppressive drugs (e.g. sirolimus, tacrolimus, rituximab, bortezomib, mycophenolate, cyclosporine) are administered post-injection and eventually in pretreatment in several clinical trials $41,139,140$, though their effects are controversial ${ }^{141,142}$. Other approaches are emerging such as plasmapheresis ${ }^{141,142}$, editing AAV capsids to eradicate epitopes that induce NAb generation ${ }^{143}$, using tolerogenic nanoparticles ${ }^{144,145}$, and the incorporation in the transgene of microRNAs (miR) target sequences integrated in the expression cassette that specifically repress translation in antigen-presenting cells $(\mathrm{APCS})^{146,147}$ or oligonucleotide sequences that inhibit toll-like receptor 9 (TLR9) activation (in development by George Church's laboratory, Harvard Medical School, patent WO2017214378A1).

\section{Future development and perspectives}

New AAV serotypes with broad CNS transduction after IV delivery

Over the last decade, significant efforts have been expended in updating the natural repertoire of viral vectors as well as engineering new serotypes ${ }^{148}$. Using the Cre recombination-based AAV targeted evolution (CREATE) technique, new AAV variants have been isolated, some able to homogenously transduce the central nervous system, especially neurons and astrocytes, after intravenous injection in mice ${ }^{149,150}$, and potentially in NHP although clear evidence of efficacy remain to bedemonstrated. Improved CNS transduction is linked to Ly6 which is not expressed in all mouse lines and not in NHP151,152. Indeed a major challenge is to identify capsids that will be able to efficiently pass the BBB and in mice, NHPs and human subjects. In addition, the selected capsids should be compatible for large scale production.

Blood Brain barrier opening as a solution to enhance CNS targeting

30 Temporary disruption of the BBB might help delivery in the brain parenchyma. Osmotic 31 disruption of the BBB with intra-arterial injection of mannitol has been widely studied and 32 allows for delivery of a variety of drugs and agents into the CNS, including viral vectors ${ }^{153}$. 
1 However, this technique induces a diffuse opening of the BBB, precluding for targeted delivery

2 of drugs and is potentially associated with significant neurological side effects.

3 Ultrasound-induced transitory disruption of the BBB is another technique that has gained

4 increasing interest since Hynynen et al. demonstrated that the IV injection of preformed gas bubbles prior to low intensity pulsed ultrasound (US) sonications allowed for a reduction of the acoustic pressure necessary to safely open the BBB in rabbits ${ }^{154}$. The interaction between US and injected microbubbles is essential for opening of the BBB, and mechanisms of BBB disruption may include transcytosis, cell fenestrations, and opening of tight junctions ${ }^{155}$. USinduced BBB disruption can be monitored with MRI, as a contrast enhancement in T1weighted sequences after gadolinium injection ${ }^{154}$ and is limited to the US beam ${ }^{156}$. The safety of the technic has been assessed through pre-clinical studies. With optimized parameters, histological side effects are limited to red blood cell extravasation and petechial bleeding ${ }^{157}$ after both single or multiple US sessions ${ }^{158}$. BBB disruption may induce a transitory sterile inflammatory response ${ }^{159}$. Recent studies have confirmed that the technic was clinically well-tolerated in non-human primates ${ }^{160}$. This technic was used to deliver an AAV1/2 viral vector in a targeted manner to the striatum of rats. Transduction observed was mainly restricted to neurons and stable during more than one year ${ }^{161}$. Two main approaches have been developed in order to bypass the skull interface that induces attenuation and distortion of the ultrasound beam. In one case, InSightec (Haifa, Israel) developed a 512-element phased-array transducer, the ExAblate ${ }^{\circledR} 4000$ system, that allows a transcranial and noninvasive opening of the BBB (McDannold et al. 2010). On-going clinical trials are currently evaluating the safety of the ExAblate ${ }^{\circledR}$ system for drug delivery after BBB disruption (NCT02343991, NCT02253212). In another case, CarThera SAS (Paris, France) designed an implantable device, the SonoCloud ${ }^{\circledR}$ device, which can be plugged into the skull, and activated through a transdermal needle ${ }^{156}$. Interim results of the first clinical trial (SONOCLOUD, NCT02253212) evaluating the safety of this system in adult patients treated for recurrent glioblastoma with systemic carboplatin have shown no dose limiting toxicities and no treatment-related serious adverse events ${ }^{162}$. A phase I trial (SONOKID) assessing the safety of repeated $\mathrm{BBB}$ disruptions by the SonoCloud ${ }^{\circledR}$ device in association with intravenous 30 chemotherapy in recurrent supra-tentorial malignant primitive tumors in the pediatric 31 population should begin during $2020^{163}$. More recent studies have been reported with percutaneous ultrasound but with no additional value ${ }^{164}$. 
Encapsulated cells and Optogenetics

3 Encapsulated cell technology (ECT) eventually combined with optogenetics allows the delivery

4 of treatment in a continuous or in a controlled/discontinuous ways, respectively. ECT is a concept based on the confinement of the grafted cells within a permeable device. ECT has already been shown to be well tolerated in large animals such as dogs for the treatment of intervertebral disc degeneration ${ }^{165}$, in pigs $^{166}$ and NHPs ${ }^{167}$ for Alzheimer's disease. Moreover, ECT has already been translated to clinical studies where the safety, feasibility, and tolerability of procedure has been shown e.g the delivery of neurotrophic factor in disorders of eye (168-170; clinicalTrial.gov NCT00447980, NCT00447993, NCT02228304, NCT00447954), in Alzheimer's disease (171; NCT01163825), in Huntington's disease $^{172,173}$ and in amyotrophic lateral sclerosis ${ }^{174}$. Moreover delivery of anti-amyloid immunotherapy by ECT is described in AD patients ${ }^{175,176}$. Thus, ECT provides an innovative approach for the local and systemic delivery of a recombinant protein in the CNS.

The optogenetics approach uses optical methods to modulate the cellular expression of molecules, which are activated by irradiation with light energy by genetic engineering to control/regulate cellular function or intracellular signal transduction ${ }^{177}$. One of the challenges of optogenetics is its translatability to the clinic. Many improvements in optogenetic technologies in NHPs have been performed to exert precise control of specific cells or brain regions at the millisecond timescale and to reliably transduce cells and readout the optically

21 induced neural modulation ${ }^{178,179}$. A new optogenetic approach has been described by Ruiz et 22 al., 2013 in which the native dura is replaced with optically transparent artificial dura allowing visual monitoring of the expression of the optogenetic agent over time.

The first optogenetic study of NHP was performed in $2009^{180}$ and followed by numerous studies performed to study the link between brain function and behavior using optogenetic stimulation $^{181,182}$. None of the optogenetic studies allowing the delivery of treatment was performed in NPH. However, many applications of optogenetics in CNS diseases (Stroke, Epilepsy, MS, AD, PD) were described by Ordaz et al., 2017. One of the major obstacles to widely use optogenetic tools in patients remains the delivery to the brain. For this reason, it 30 is essential to reduce brain tissue damage inflicted by probe penetrations and light-induced 31 heating for optogenetic procedures. Once these problems are overcome, optogenetics can be an advantageous tool to treat neurological diseases providing an alternative treatment with 
1 less side effects than current therapies ${ }^{183}$. The first patient dosed with optogenetics was

2 treated for retinitis pigmentosa in a clinical trial conducted by RetroSense Therapeutic in 2016.

3 More recently, one Phase I/II clinical trial of optogenetics for vision restoration is registered

4 (NCT02556736, sponsor Allergan; NCT03326336, sponsor GenSight), but no results have been 5 published to date.

$7 \quad$ Hematopoietic Stem cell gene therapy to treat CNS diseases

8 Hematopoietic stem cell transplantation (HSCT) is the best example of stem-cell therapy and 9 is currently an established treatment for several neurologically devastating inherited 10 metabolic diseases, including adrenoleukodystrophy and LSDs ${ }^{21,22}$. In LSDs, donor-derived 11 microglia cells of myeloid origin are thought to be the source of enzyme after HSCT, crosscorrecting the metabolic defect in affected host cells ${ }^{184}$. In addition, engrafted donor-derived cells may potentially help in reducing accumulated toxic substrates in the brain. Of importance, there is evidence that stem cells are not only replacing dying cells, but are also regulating inflammation and immune responses and have pro-neurogenic effects ${ }^{185}$. Numerous studies support the notion of using stem cells as a treatment for inherited diseases like $\mathrm{LSDs}^{184}, \mathrm{HD}$, but also for complex diseases like $A D, P D, A L S^{186,187}$. Further pre-clinical and clinical studies are needed to ensure the safety and efficacy of these treatment options ${ }^{187}$.

\section{Conclusion}

21 The recent beneficial results demonstrated in phase I-II studies in human patients together 22 with improved vector technology have placed gene therapy for CNS diseases in a new development paradyme. These approaches are no longer restricted to rare genetic diseases, but are being applied to common disease indications and pathways significantly expanding the scope of gene therapy for CNS indications This expansion requires simplifying delivery protocols and anticipating the increasing need of vector production, particularly for IV targeting. Treating an increasing number of patients requires standardized delivery protocols suitable for adaptation in multiple centers around the world. Further, manufacturability is a central component in expanding the GT field; not only the production of high quality and high quantity of vectors to meet future clinical demand, but also the cost and our capacity to make new gene therapy products accessible to all patients. 


\section{References}

1. Daneman R, Prat A. The Blood-Brain Barrier. Cold Spring Harb Perspect Biol;7 . Epub ahead of print 2015. DOI: 10.1101/CSHPERSPECT.A020412.

2. Zlokovic B V. The Blood-Brain Barrier in Health and Chronic Neurodegenerative Disorders. Neuron 2008;57:178-201.

3. Hocquemiller M, Giersch L, Audrain M, et al. Adeno-Associated Virus-Based Gene Therapy for CNS Diseases. Hum Gene Ther 2016;27:478-96.

4. Tărlungeanu DC, Novarino G. Genomics in neurodevelopmental disorders: an avenue to personalized medicine. Exp Mol Med 2018;50:100.

5. Gray SJ. Gene therapy and neurodevelopmental disorders. Neuropharmacology 2013;68:136142.

6. $\quad$ Drew L. Gene therapy targets epilepsy. Nature 2018;564:S10-S11.

7. Kwiatkowska A, Nandhu MS, Behera P, et al. Strategies in gene therapy for glioblastoma. Cancers (Basel) 2013;5:1271-305.

8. Guedon J-MG, Wu S, Zheng $\mathrm{X}$, et al. Current gene therapy using viral vectors for chronic pain. Mol Pain 2015;11:27.

9. Tardieu M, Zérah M, Husson B, et al. Intracerebral Administration of Adeno-Associated Viral Vector Serotype rh.10 Carrying Human SGSH and SUMF1 cDNAs in Children with Mucopolysaccharidosis Type IIIA Disease: Results of a Phase I/II Trial. Hum Gene Ther 2014;25:506-516.

10. Tardieu M, Zérah M, Gougeon M-L, et al. Intracerebral gene therapy in children with mucopolysaccharidosis type IIIB syndrome: an uncontrolled phase 1/2 clinical trial. Lancet Neurol 2017;16:712-720.

11. Zerah M, Piguet F, Colle M-A, et al. Intracerebral Gene Therapy Using AAVrh.10-hARSA Recombinant Vector to Treat Patients with Early-Onset Forms of Metachromatic Leukodystrophy: Preclinical Feasibility and Safety Assessments in Nonhuman Primates. Hum Gene Ther Clin Dev 2015;26:113-124.

12. Mendell JR, Al-Zaidy S, Shell R, et al. Single-Dose Gene-Replacement Therapy for Spinal Muscular Atrophy. N Engl J Med 2017;377:1713-1722.

13. Meyer K, Ferraiuolo L, Schmelzer L, et al. Improving Single Injection CSF Delivery of AAV9mediated Gene Therapy for SMA: A Dose-response Study in Mice and Nonhuman Primates. Mol Ther 2015;23:477-487.

14. Bestor TH. Gene silencing as a threat to the success of gene therapy. J Clin Invest 2000;105:409-11.

15. Rindt $\mathrm{H}$, Yen $\mathrm{P}-\mathrm{F}$, Thebeau $\mathrm{CN}$, et al. Replacement of huntingtin exon 1 by trans-splicing. Cell Mol Life Sci 2012;69:4191-4204.

16. Boussicault L, Alves $S$, Lamazière $A$, et al. CYP46A1, the rate-limiting enzyme for cholesterol degradation, is neuroprotective in Huntington's disease. Brain 2016;139:953-70.

17. Burlot M-A, Braudeau J, Michaelsen-Preusse K, et al. Cholesterol 24-hydroxylase defect is implicated in memory impairments associated with Alzheimer-like Tau pathology. Hum Mol Genet 2015;24:5965-5976.

18. Rose $\mathrm{C}$, Dorard $\mathrm{E}$, Audrain $\mathrm{M}$, et al. Transient increase in SAPP $\alpha$ secretion in response to $A B 1$ 42 oligomers: an attempt of neuronal self-defense? Neurobiol Aging 2018;61:23-35.

19. Audrain M, Souchet B, Alves S, et al. $\beta$ APP Processing Drives Gradual Tau Pathology in an AgeDependent Amyloid Rat Model of Alzheimer's Disease. Cereb Cortex 2017;1-18.

20. Hulou MM, Cho C-F, Chiocca EA, et al. Experimental therapies. In: Handbook of clinical neurology; pp. 183-197.

21. Sessa M, Lorioli L, Fumagalli F, et al. Lentiviral haemopoietic stem-cell gene therapy in earlyonset metachromatic leukodystrophy: an ad-hoc analysis of a non-randomised, open-label, phase 1/2 trial. Lancet 2016;388:476-487.

22. Eichler F, Duncan C, Musolino PL, et al. Hematopoietic Stem-Cell Gene Therapy for Cerebral Adrenoleukodystrophy. N Engl J Med 2017;377:1630-1638. 
23. Piguet F, Alves S, Cartier N. Clinical Gene Therapy for Neurodegenerative Diseases: Past,

Present, and Future. Human Gene Therapy 2017;28:988-1003.

24. Gao G, Vandenberghe L, Wilson J. New Recombinant Serotypes of AAV Vectors. Curr Gene Ther 2005;5:285-297.

25. Srivastava A, Carter BJ. AAV Infection: Protection from Cancer. Hum Gene Ther 2017;28:323327.

26. Nault JC, Mami I, La Bella T, et al. Wild-type AAV insertions in hepatocellular carcinoma do not inform debate over genotoxicity risk of vectorized AAV. Molecular Therapy 2016;24:660-661.

27. Hastie E, Samulski RJ. Adeno-Associated Virus at 50: A Golden Anniversary of Discovery, Research, and Gene Therapy Success - A Personal Perspective. Human Gene Therapy 2015;26:257-265.

28. Ginn SL, Amaya AK, Alexander IE, et al. Gene therapy clinical trials worldwide to 2017: An update. Journal of Gene Medicine 2018;20:e3015.

29. Pillay S, Carette JE. Host determinants of adeno-associated viral vector entry. Current Opinion in Virology 2017;24:124-131.

30. Castle MJ, Turunen HT, Vandenberghe LH, et al. Controlling AAV tropism in the nervous system with natural and engineered capsids. In: Methods in Molecular Biology. Humana Press Inc.; pp. 133-149.

31. Vandenberghe LH, Wilson JM, Gao G. Tailoring the AAV vector capsid for gene therapy. Gene Therapy 2009;16:311-319.

32. Auricchio A. Exchange of surface proteins impacts on viral vector cellular specificity and transduction characteristics: the retina as a model. Hum Mol Genet 2001;10:3075-3081.

33. Hadaczek P, Stanek L, Ciesielska A, et al. Widespread AAV1- and AAV2-mediated transgene expression in the nonhuman primate brain: implications for Huntington's disease. Mol Ther Methods Clin Dev 2016;3:16037.

34. Bartus RT, Baumann TL, Siffert J, et al. Safety/feasibility of targeting the substantia nigra with AAV2-neurturin in Parkinson patients. Neurology 2013;80:1698-701.

35. Chien $\mathrm{Y}-\mathrm{H}$, Lee N-C, Tseng $\mathrm{S}-\mathrm{H}$, et al. Efficacy and safety of AAV2 gene therapy in children with aromatic L-amino acid decarboxylase deficiency: an open-label, phase 1/2 trial. Lancet Child Adolesc Heal 2017;1:265-273.

36. Mittermeyer G, Christine CW, Rosenbluth KH, et al. Long-Term Evaluation of a Phase 1 Study of AADC Gene Therapy for Parkinson's Disease. Hum Gene Ther 2012;23:377-381.

37. Colle M-A, Piguet $F$, Bertrand $L$, et al. Efficient intracerebral delivery of AAV5 vector encoding human ARSA in non-human primate. Hum Mol Genet 2010;19:147-158.

38. Tardieu M, Zérah M, Husson B, et al. Intracerebral Administration of Adeno-Associated Viral Vector Serotype rh.10 Carrying Human SGSH and SUMF1 cDNAs in Children with Mucopolysaccharidosis Type IIIA Disease: Results of a Phase I/II Trial . Hum Gene Ther . Epub ahead of print 2014. DOI: 10.1089/hum.2013.238.

39. Foust KD, Wang X, McGovern VL, et al. Rescue of the spinal muscular atrophy phenotype in a mouse model by early postnatal delivery of SMN. Nat Biotechnol 2010;28:271-4.

40. Murrey DA, Naughton BJ, Duncan FJ, et al. Feasibility and Safety of Systemic rAAV9-h NAGLU Delivery for Treating Mucopolysaccharidosis IIIB: Toxicology, Biodistribution, and Immunological Assessments in Primates. Hum Gene Ther Clin Dev 2014;25:72-84.

41. Mendell JR, Al-Zaidy S, Shell R, et al. Single-Dose Gene-Replacement Therapy for Spinal Muscular Atrophy. N Engl J Med 2017;377:1713-1722.

42. Lipinski DM, Reid CA, Boye SL, et al. AAV Vectors II 314. Systemic Vascular Transduction Following Intravenous Injection of Capsid Mutant Adeno-Associated Virus. 2015 . Epub ahead of print 2015. DOI: 10.1038/mt.2015.74.

43. Gessler DJ, Tai PWL, Li J, et al. Intravenous infusion of AAV for widespread gene delivery to the nervous system. In: Methods in Molecular Biology. Humana Press Inc.; pp. 143-163.

44. Deverman BE, Pravdo PL, Simpson BP, et al. Cre-dependent selection yields AAV variants for widespread gene transfer to the adult brain. Nat Biotechnol 2016;34:204-209. 
45. Hordeaux J, Wang Q, Katz N, et al. The Neurotropic Properties of AAV-PHP.B Are Limited to C57BL/6J Mice. Mol Ther 2018;26:664-668.

46. Zufferey R, Dull T, Mandel RJ, et al. Self-Inactivating Lentivirus Vector for Safe and Efficient In Vivo Gene Delivery. J Virol 1998;72:9873-9880.

47. Escors D, Breckpot K. Lentiviral vectors in gene therapy: Their current status and future potential. Archivum Immunologiae et Therapiae Experimentalis 2010;58:107-119.

48. Delzor A, Aurélie D, Escartin C, et al. Lentiviral vectors: a powerful tool to target astrocytes in vivo. Curr Drug Targets 2013;14:1336-46.

49. Hastie E, Cataldi M, Marriott I, et al. Understanding and altering cell tropism of vesicular stomatitis virus. Virus Research 2013;176:16-32.

50. Carlotti F, Bazuine $M$, Kekarainen $T$, et al. Lentiviral vectors efficiently transduce quiescent mature 3T3-L1 adipocytes. Mol Ther 2004;9:209-217.

51. Geng X, Doitsh G, Yang Z, et al. Efficient delivery of lentiviral vectors into resting human CD4 T cells. Gene Ther 2014;21:444-449.

52. Jakobsson J, Lundberg C. Lentiviral vectors for use in the central nervous system. Molecular Therapy 2006;13:484-493.

53. Cartier N, Hacein-Bey-Abina S, Bartholomae CC, et al. Hematopoietic stem cell gene therapy with a lentiviral vector in X-linked adrenoleukodystrophy. Science 2009;326:818-23.

54. Staal FJT, Aiuti A, Cavazzana M. Autologous Stem-Cell-Based Gene Therapy for Inherited Disorders: State of the Art and Perspectives. Frontiers in Pediatrics 2019;7:443.

55. Stein S, Ott MG, Schultze-Strasser S, et al. Genomic instability and myelodysplasia with monosomy 7 consequent to EVI1 activation after gene therapy for chronic granulomatous disease. Nat Med 2010;16:198-204.

56. Zychlinski D, Schambach A, Modlich U, et al. Physiological promoters reduce the genotoxic risk of integrating gene vectors. Mol Ther 2008;16:718-725.

57. Poletti V, Charrier S, Corre G, et al. Preclinical Development of a Lentiviral Vector for Gene Therapy of X-Linked Severe Combined Immunodeficiency. Mol Ther - Methods Clin Dev 2018;9:257-269.

58. Doi K, Takeuchi Y. Gene therapy using retrovirus vectors: vector development and biosafety at clinical trials. Uirusu 2015;65:27-36.

59. Rothe M, Modlich U, Schambach A. Biosafety Challenges for Use of Lentiviral Vectors in Gene Therapy. Curr Gene Ther 2014;13:453-468.

60. Katsouri L, Lim YM, Blondrath K, et al. PPARY-coactivator-1 $\alpha$ gene transfer reduces neuronal loss and amyloid- $\beta$ generation by reducing $\beta$-secretase in an Alzheimer's disease model. Proc Natl Acad Sci U S A 2016;113:12292-12297.

61. Palfi S, Gurruchaga JM, Lepetit H, et al. Long-Term Follow-Up of a Phase I/II Study of ProSavin, a Lentiviral Vector Gene Therapy for Parkinson's Disease. Hum Gene Ther Clin Dev 2018;29:148-155.

62. Azzouz M, Martin-Rendon E, Barber RD, et al. Multicistronic lentiviral vector-mediated striatal gene transfer of aromatic L-amino acid decarboxylase, tyrosine hydroxylase, and GTP cyclohydrolase I induces sustained transgene expression, dopamine production, and functional improvement in a rat model of Parkinson's disease. J Neurosci 2002;22:1030210312.

63. Blagbrough IS, Zara C. Animal Models for Target Diseases in Gene Therapy - using DNA and siRNA Delivery Strategies. Pharm Res 2009;26:1-18.

64. Hattori N, Sato S. Animal models of Parkinson's disease: similarities and differences between the disease and models. Neuropathology 2007;27:479-83.

65. Lasbleiz C, Mestre-Francés N, Devau G, et al. Combining Gene Transfer and Nonhuman Primates to Better Understand and Treat Parkinson's Disease. Front Mol Neurosci 2019;12:10.

66. Gopinath C, Nathar TJ, Ghosh A, et al. Contemporary Animal Models For Human Gene Therapy Applications. Curr Gene Ther 2015;15:531-40.

67. Dawson T, Mandir A, Lee M. Animal models of PD: pieces of the same puzzle? Neuron 
2002;35:219-22.

68. Wolfe JH. Gene therapy in large animal models of human genetic diseases. Introduction. ILAR J 2009;50:107-11.

69. Bankiewicz KS, Sudhakar V, Samaranch L, et al. AAV viral vector delivery to the brain by shapeconforming MR-guided infusions. J Control Release 2016;240:434-442.

70. Samaranch L, Salegio EA, San Sebastian W, et al. Strong cortical and spinal cord transduction after AAV7 and AAV9 delivery into the cerebrospinal fluid of nonhuman primates. Hum Gene Ther 2013;24:526-32.

71. Salegio EA, Samaranch L, Kells AP, et al. Axonal transport of adeno-associated viral vectors is serotype-dependent. Gene Ther 2013;20:348-352.

72. Salegio EA, Samaranch L, Kells AP, et al. Axonal transport of adeno-associated viral vectors is serotype-dependent. Gene Ther 2013;20:348-352.

73. Kells AP, Forsayeth J, Bankiewicz KS. Glial-derived neurotrophic factor gene transfer for Parkinson's disease: anterograde distribution of AAV2 vectors in the primate brain. Neurobiol Dis 2012;48:228-35.

74. Ciesielska A, Mittermeyer G, Hadaczek P, et al. Anterograde Axonal Transport of AAV2-GDNF in Rat Basal Ganglia. Mol Ther 2011;19:922-927.

75. Green F, Samaranch L, Zhang HS, et al. Axonal transport of AAV9 in nonhuman primate brain. Gene Ther 2016;23:520-6.

76. Evers MM, Miniarikova J, Juhas S, et al. AAV5-miHTT Gene Therapy Demonstrates Broad Distribution and Strong Human Mutant Huntingtin Lowering in a Huntington's Disease Minipig Model. Mol Ther . Epub ahead of print 2018. DOI: 10.1016/j.ymthe.2018.06.021.

77. Hocquemiller M, Hemsley KM, Douglass ML, et al. AAVrh10 Vector Corrects Disease Pathology in MPS IIIA Mice and Achieves Widespread Distribution of SGSH in Large Animal Brains. Mol Ther - Methods Clin Dev 2020;17:174-187.

78. Kordower JH, Emborg ME, Bloch J, et al. Neurodegeneration Prevented by Lentiviral Vector Delivery of GDNF in Primate Models of Parkinson's Disease. Science (80- ) 2000;290:767-773.

79. Jarraya B, Boulet S, Scott Ralph G, et al. Dopamine Gene Therapy for Parkinson's Disease in a Nonhuman Primate Without Associated Dyskinesia. Sci Transl Med 2009;1:2ra4-2ra4.

80. Linterman KS, Palmer DN, Kay GW, et al. Lentiviral-mediated gene transfer to the sheep brain: implications for gene therapy in Batten disease. Hum Gene Ther 2011;22:1011-20.

81. Duque SI, Arnold WD, Odermatt $\mathrm{P}$, et al. A large animal model of spinal muscular atrophy and correction of phenotype. Ann Neurol 2015;77:399-414.

82. Katz ML, Tecedor $L$, Chen $Y$, et al. AAV gene transfer delays disease onset in a TPP1-deficient canine model of the late infantile form of Batten disease. Sci Transl Med 2015;7:313ra180313 ra180.

83. Samaranch L, Salegio EA, San Sebastian W, et al. Adeno-associated virus serotype 9 transduction in the central nervous system of nonhuman primates. Hum Gene Ther 2012;23:382-9.

84. Samaranch L, Sebastian WS, Kells AP, et al. AAV9-mediated expression of a non-self protein in nonhuman primate central nervous system triggers widespread neuroinflammation driven by antigen-presenting cell transduction. Mol Ther 2014;22:329-337.

85. Rosenberg JB, Sondhi D, Rubin DG, et al. Comparative Efficacy and Safety of Multiple Routes of Direct CNS Administration of Adeno-Associated Virus Gene Transfer Vector Serotype rh.10 Expressing the Human Arylsulfatase A cDNA to Nonhuman Primates. Hum Gene Ther Clin Dev 2014;25:164-177.

86. Rosenberg JB, Kaplitt MG, De BP, et al. AAVrh.10-Mediated APOE2 Central Nervous System Gene Therapy for APOE4-Associated Alzheimer's Disease. Hum Gene Ther Clin Dev 2018;29:24-47.

87. Passini MA, Bu J, Richards AM, et al. Translational Fidelity of Intrathecal Delivery of SelfComplementary AAV9-Survival Motor Neuron 1 for Spinal Muscular Atrophy. Hum Gene Ther 2014;25:619-630. 
88. Hinderer $\mathrm{C}$, Bell $\mathrm{P}$, Vite $\mathrm{CH}$, et al. Widespread gene transfer in the central nervous system of cynomolgus macaques following delivery of AAV9 into the cisterna magna. Mol Ther Methods Clin Dev 2014;1:14051.

89. Haurigot V, Marcó S, Ribera A, et al. Whole body correction of mucopolysaccharidosis IIIA by intracerebrospinal fluid gene therapy. J Clin Invest 2013;123:3254-3271.

90. Gray SJ, Matagne V, Bachaboina L, et al. Preclinical differences of intravascular AAV9 delivery to neurons and glia: a comparative study of adult mice and nonhuman primates. Mol Ther 2011;19:1058-69.

91. Duque $\mathrm{S}$, Joussemet B, Riviere $\mathrm{C}$, et al. Intravenous Administration of Self-complementary AAV9 Enables Transgene Delivery to Adult Motor Neurons. Mol Ther 2009;17:1187-1196.

92. Bucher T, Dubreil L, Colle M-A, et al. Intracisternal delivery of AAV9 results in oligodendrocyte and motor neuron transduction in the whole central nervous system of cats. Gene Ther 2014;21:522-528.

93. Gurda BL, De Guilhem De Lataillade A, Bell P, et al. Evaluation of AAV-mediated Gene Therapy for Central Nervous System Disease in Canine Mucopolysaccharidosis VII. Mol Ther 2016;24:206-216.

94. Hinderer C, Bell P, Louboutin J-P, et al. Neonatal Systemic AAV Induces Tolerance to CNS Gene Therapy in MPS I Dogs and Nonhuman Primates. Mol Ther 2015;23:1298-1307.

95. Borel F, Gernoux G, Cardozo B, et al. Therapeutic rAAVrh10 Mediated SOD1 Silencing in Adult SOD1 ${ }^{\text {G93A }}$ Mice and Nonhuman Primates. Hum Gene Ther 2016;27:19-31.

96. Bevan AK, Duque S, Foust KD, et al. Systemic Gene Delivery in Large Species for Targeting Spinal Cord, Brain, and Peripheral Tissues for Pediatric Disorders. Mol Ther 2011;19:19711980.

97. Yang B, Li S, Wang $\mathrm{H}$, et al. Global CNS transduction of adult mice by intravenously delivered rAAVrh.8 and rAAVrh.10 and nonhuman primates by rAAVrh.10. In: Molecular Therapy. Nature Publishing Group; pp. 1299-1309.

98. Borel F, Gernoux G, Sun H, et al. Safe and effective superoxide dismutase 1 silencing using artificial microRNA in macaques. Sci Transl Med 2018;10:eaau6414.

99. Hinderer C, Bell P, Katz N, et al. Evaluation of Intrathecal Routes of Administration for AdenoAssociated Viral Vectors in Large Animals. Hum Gene Ther 2018;29:15-24.

100. Bravo-Hernandez M, Tadokoro T, Navarro MR, et al. Spinal subpial delivery of AAV9 enables widespread gene silencing and blocks motoneuron degeneration in ALS. Nat Med 2020;26:118-130.

101. Tadokoro T, Miyanohara A, Navarro M, et al. Subpial adeno-associated virus 9 (AAV9) vector delivery in adult mice. J Vis Exp;2017 . Epub ahead of print July 13, 2017. DOI: 10.3791/55770.

102. Wolf DA, Banerjee S, Hackett PB, et al. Gene therapy for neurologic manifestations of mucopolysaccharidoses. Expert Opin Drug Deliv 2015;12:283-296.

103. Hordeaux J, Dubreil L, Robveille C, et al. Long-term neurologic and cardiac correction by intrathecal gene therapy in Pompe disease. Acta Neuropathol Commun 2017;5:66.

104. Hordeaux J, Hinderer C, Goode T, et al. Toxicology Study of Intra-Cisterna Magna AdenoAssociated Virus 9 Expressing Human Alpha-L-Iduronidase in Rhesus Macaques. Mol Ther Methods Clin Dev 2018;10:79-88.

105. Kim I, Paek S, Nelson BD, et al. Implementation of a chronic unilateral intraparenchymal drug delivery system in a swine model. J Neurosci Methods 2014;227:29-34.

106. Brady ML, Raghavan R, Alexander A, et al. Pathways of Infusate Loss during ConvectionEnhanced Delivery into the Putamen Nucleus. Stereotact Funct Neurosurg 2013;91:69-78.

107. Belova E, Shaffer CL, Trapa PE. Insights from mathematical modeling for convection-enhanced intraputamenal delivery of GDNF. Med Biol Eng Comput 2017;55:2069-2077.

108. Vazquez LC, Hagel E, Willenberg BJ, et al. Polymer-coated cannulas for the reduction of backflow during intraparenchymal infusions. J Mater Sci Mater Med 2012;23:2037-2046.

109. Ung $\mathrm{TH}$, Malone $\mathrm{H}$, Canoll $\mathrm{P}$, et al. Convection-enhanced delivery for glioblastoma: targeted delivery of antitumor therapeutics. CNS Oncol 2015;4:225-34. 
110. Lueshen $\mathrm{E}$, Tangen $\mathrm{K}$, Mehta Al, et al. Backflow-free catheters for efficient and safe convection-enhanced delivery of therapeutics. Med Eng Phys 2017;45:15-24.

111. Krauze MT, Saito R, Noble $C$, et al. Reflux-free cannula for convection-enhanced high-speed delivery of therapeutic agents. J Neurosurg 2005;103:923-9.

112. Lewis $\mathrm{O}$, Woolley $\mathrm{M}$, Johnson $\mathrm{D}$, et al. Chronic, intermittent convection-enhanced delivery devices. J Neurosci Methods 2016;259:47-56.

113. Debinski W, Tatter SB. Convection-enhanced delivery for the treatment of brain tumors. Expert Rev Neurother 2009;9:1519-1527.

114. Fan $\mathrm{X}$, Nelson $\mathrm{BD}, \mathrm{Ai} \mathrm{Y}$, et al. Continuous intraputamenal convection-enhanced delivery in adult rhesus macaques. J Neurosurg 2015;123:1569-1577.

115. Debinski W, Tatter SB. Convection-enhanced delivery for the treatment of brain tumors. Expert Rev Neurother 2009;9:1519-27.

116. Lewis $\mathrm{O}$, Woolley $\mathrm{M}$, Johnson $\mathrm{D}$, et al. Chronic, intermittent convection-enhanced delivery devices. Journal of Neuroscience Methods 2016;259:47-56.

117. Bienemann A, White $E$, Woolley $M$, et al. The development of an implantable catheter system for chronic or intermittent convection-enhanced delivery. J Neurosci Methods 2012;203:284291.

118. Vogelbaum MA, Brewer C, Barnett GH, et al. First-in-human evaluation of the Cleveland Multiport Catheter for convection-enhanced delivery of topotecan in recurrent high-grade glioma: results of pilot trial 1. J Neurosurg 2019;130:476-485.

119. Christine CW, Bankiewicz KS, Van Laar AD, et al. Magnetic resonance imaging-guided phase 1 trial of putaminal $A A D C$ gene therapy for Parkinson's disease. Ann Neurol 2019;85:704-714.

120. Bankiewicz KS, Sudhakar V, Samaranch L, et al. AAV viral vector delivery to the brain by shapeconforming MR-guided infusions. J Control Release 2016;240:434-442.

121. Nayak S, Herzog RW. Progress and prospects: immune responses to viral vectors. Gene Ther 2010;17:295-304.

122. Mingozzi F, Maus M V, Hui DJ, et al. CD8+ T-cell responses to adeno-associated virus capsid in humans. Nat Med 2007;13:419-422.

123. Basner-Tschakarjan E, Mingozzi F. Cell-Mediated Immunity to AAV Vectors, Evolving Concepts and Potential Solutions. Front Immunol 2014;5:350.

124. Calcedo R, Wilson JM. Humoral Immune Response to AAV. Front Immunol 2013;4:341.

125. Rogers GL, Martino AT, Aslanidi G V., et al. Innate Immune Responses to AAV Vectors. Front Microbiol 2011;2:194.

126. Calcedo R, Vandenberghe LH, Gao G, et al. Worldwide Epidemiology of Neutralizing Antibodies to Adeno-Associated Viruses. J Infect Dis 2009;199:381-390.

127. Veron $P$, Leborgne $C$, Monteilhet $V$, et al. Humoral and cellular capsid-specific immune responses to adeno-associated virus type 1 in randomized healthy donors. J Immunol 2012;188:6418-24.

128. Boutin $S$, Monteilhet $V$, Veron $P$, et al. Prevalence of Serum IgG and Neutralizing Factors Against Adeno-Associated Virus (AAV) Types 1, 2, 5, 6, 8, and 9 in the Healthy Population: Implications for Gene Therapy Using AAV Vectors. Hum Gene Ther 2010;21:704-712.

129. Wang Z, Tapscott SJ, Chamberlain JS, et al. Immunity and AAV-Mediated Gene Therapy for Muscular Dystrophies in Large Animal Models and Human Trials. Front Microbiol 2011;2:201.

130. Banugaria SG, Prater SN, Ng Y-K, et al. The impact of antibodies on clinical outcomes in diseases treated with therapeutic protein: lessons learned from infantile Pompe disease. Genet Med 2011;13:729-36.

131. Berrier KL, Kazi ZB, Prater SN, et al. CRIM-negative infantile Pompe disease: characterization of immune responses in patients treated with ERT monotherapy. Genet Med 2015;17:912-8.

132. Ferreira V, Petry H, Salmon F. Immune Responses to AAV-Vectors, the Glybera Example from Bench to Bedside. Front Immunol;5 . Epub ahead of print 2014. DOI: 10.3389/fimmu.2014.00082.

133. Gaudet D, Méthot J, Déry S, et al. Efficacy and long-term safety of alipogene tiparvovec 
(AAV1-LPLS447X) gene therapy for lipoprotein lipase deficiency: an open-label trial. Gene Ther 2013;20:361-369.

134. Manno CS, Pierce GF, Arruda VR, et al. Successful transduction of liver in hemophilia by AAVFactor IX and limitations imposed by the host immune response. Nat Med 2006;12:342-347.

135. Marks WJ, Bartus RT, Siffert J, et al. Gene delivery of AAV2-neurturin for Parkinson's disease: a double-blind, randomised, controlled trial. Lancet Neurol 2010;9:1164-1172.

136. Christine CW, Starr PA, Larson PS, et al. Safety and tolerability of putaminal AADC gene therapy for Parkinson disease. Neurology 2009;73:1662-1669.

137. McPhee SWJ, Janson CG, Li C, et al. Immune responses to AAV in a phase I study for Canavan disease. J Gene Med 2006;8:577-588.

138. Kaplitt MG, Feigin A, Tang C, et al. Safety and tolerability of gene therapy with an adenoassociated virus (AAV) borne GAD gene for Parkinson's disease: an open label, phase I trial. Lancet 2007;369:2097-2105.

139. Mingozzi F, Chen Y, Edmonson SC, et al. Prevalence and pharmacological modulation of humoral immunity to AAV vectors in gene transfer to synovial tissue. Gene Ther 2013;20:41724.

140. Corti M, Liberati C, Smith BK, et al. Safety of Intradiaphragmatic Delivery of Adeno-Associated Virus-Mediated Alpha-Glucosidase (rAAV1-CMV- $h$ GAA ) Gene Therapy in Children Affected by Pompe Disease. Hum Gene Ther Clin Dev 2017;28:208-218.

141. Montenegro-Miranda PS, Bloemendaal L ten, Kunne C, et al. Mycophenolate Mofetil Impairs Transduction of Single-Stranded Adeno-Associated Viral Vectors. Hum Gene Ther 2011;22:605-612.

142. Unzu C, Hervás-Stubbs S, Sampedro A, et al. Transient and intensive pharmacological immunosuppression fails to improve AAV-based liver gene transfer in non-human primates. J Transl Med 2012;10:122.

143. Tseng Y-S, Agbandje-McKenna M. Mapping the AAV Capsid Host Antibody Response toward the Development of Second Generation Gene Delivery Vectors. Front Immunol 2014;5:9.

144. Kishimoto TK, Ferrari JD, LaMothe RA, et al. Improving the efficacy and safety of biologic drugs with tolerogenic nanoparticles. Nat Nanotechnol 2016;11:890-899.

145. Meliani A, Boisgerault $F$, Hardet R, et al. Antigen-selective modulation of AAV immunogenicity with tolerogenic rapamycin nanoparticles enables successful vector re-administration. Nat Commun 2018;9:4098.

146. Majowicz A, Maczuga P, Kwikkers KL, et al. Mir-142-3p target sequences reduce transgenedirected immunogenicity following intramuscular adeno-associated virus 1 vector-mediated gene delivery. J Gene Med 2013;15:219-232.

147. Annoni A, Brown BD, Cantore A, et al. In vivo delivery of a microRNA-regulated transgene induces antigen-specific regulatory $T$ cells and promotes immunologic tolerance. Blood 2009;114:5152-5161.

148. Keeler AM, EIMallah MK, Flotte TR. Gene Therapy 2017: Progress and Future Directions. Clin Transl Sci 2017;10:242-248.

149. Deverman BE, Pravdo PL, Simpson BP, et al. Cre-dependent selection yields AAV variants for widespread gene transfer to the adult brain. Nat Biotechnol 2016;34:204-209.

150. Chan KY, Jang MJ, Yoo BB, et al. Engineered AAVs for efficient noninvasive gene delivery to the central and peripheral nervous systems. Nat Neurosci 2017;20:1172-1179.

151. Huang $Q$, Chan KY, Tobey IG, et al. Delivering genes across the blood-brain barrier: LY6A, a novel cellular receptor for AAV-PHP.B capsids. bioRxiv 2019;538421.

152. Hordeaux J, Yuan Y, Clark PM, et al. The GPI-Linked Protein LY6A Drives AAV-PHP.B Transport across the Blood-Brain Barrier. Mol Ther 2019;27:912-921.

153. Garg T, Bhandari S, Rath G, et al. Current strategies for targeted delivery of bio-active drug molecules in the treatment of brain tumor. J Drug Target 2015;23:865-887.

154. Hynynen K, McDannold N, Vykhodtseva N, et al. Noninvasive MR Imaging-guided Focal Opening of the Blood-Brain Barrier in Rabbits. Radiology 2001;220:640-646. 
155. Sheikov N, McDannold N, Vykhodtseva N, et al. Cellular mechanisms of the blood-brain barrier opening induced by ultrasound in presence of microbubbles. Ultrasound Med Biol 2004;30:979-989.

156. Beccaria K, Canney M, Goldwirt L, et al. Opening of the blood-brain barrier with an unfocused ultrasound device in rabbits. J Neurosurg 2013;119:887-98.

157. Hynynen K, McDannold N, Sheikov NA, et al. Local and reversible blood-brain barrier disruption by noninvasive focused ultrasound at frequencies suitable for trans-skull sonications. Neuroimage 2005;24:12-20.

158. Kobus T, Vykhodtseva N, Pilatou M, et al. Safety Validation of Repeated Blood-Brain Barrier Disruption Using Focused Ultrasound. Ultrasound Med Biol 2016;42:481-492.

159. McMahon D, Hynynen K. Acute Inflammatory Response Following Increased Blood-Brain Barrier Permeability Induced by Focused Ultrasound is Dependent on Microbubble Dose. Theranostics 2017;7:3989-4000.

160. Marquet F, Tung Y-S, Teichert T, et al. Noninvasive, Transient and Selective Blood-Brain Barrier Opening in Non-Human Primates In Vivo. PLoS One 2011;6:e22598.

161. Stavarache MA, Petersen N, Jurgens EM, et al. Safe and stable noninvasive focal gene delivery to the mammalian brain following focused ultrasound. J Neurosurg 2019;130:989-998.

162. Carpentier A, Canney M, Vignot A, et al. Clinical trial of blood-brain barrier disruption by pulsed ultrasound. Sci Transl Med 2016;8:343re2-343re2.

163. Beccaria K, Canney M, Bouchoux G, et al. Blood-brain barrier disruption with low-intensity pulsed ultrasound for the treatment of pediatric brain tumors: A review and perspectives. Neurosurg Focus 2020;48:E10.

164. Pouliopoulos AN, Wu SY, Burgess MT, et al. A Clinical System for Non-invasive Blood-Brain Barrier Opening Using a Neuronavigation-Guided Single-Element Focused Ultrasound Transducer. Ultrasound Med Biol 2020;46:73-89.

165. Ying J, Han Z, Zeng Y, et al. Evaluation of intervertebral disc regeneration with injection of mesenchymal stem cells encapsulated in PEGDA-microcryogel delivery system using quantitative T2 mapping: a study in canines. Am J Transl Res 2019;11:2028-2041.

166. Fjord-Larsen L, Kusk P, Tornøe J, et al. Long-term Delivery of Nerve Growth Factor by Encapsulated Cell Biodelivery in the Göttingen Minipig Basal Forebrain. Mol Ther 2010;18:2164-2172.

167. Emerich DF, Winn SR, Harper J, et al. Implants of polymer-encapsulated human NGF-secreting cells in the nonhuman primate: Rescue and sprouting of degenerating cholinergic basal forebrain neurons. J Comp Neurol 1994;349:148-164.

168. Zhang K, Hopkins JJ, Heier JS, et al. Ciliary neurotrophic factor delivered by encapsulated cell intraocular implants for treatment of geographic atrophy in age-related macular degeneration. Proc Natl Acad Sci 2011;108:6241-6245.

169. Birch DG, Bennett LD, Duncan JL, et al. Long-term Follow-up of Patients With Retinitis Pigmentosa Receiving Intraocular Ciliary Neurotrophic Factor Implants. Am J Ophthalmol 2016;170:10-14.

170. Birch DG, Weleber RG, Duncan JL, et al. Randomized Trial of Ciliary Neurotrophic Factor Delivered by Encapsulated Cell Intraocular Implants for Retinitis Pigmentosa. Am J Ophthalmol 2013;156:283-292.e1.

171. Eriksdotter-Jönhagen M, Linderoth B, Lind G, et al. Encapsulated Cell Biodelivery of Nerve Growth Factor to the Basal Forebrain in Patients with Alzheimer's Disease. Dement Geriatr Cogn Disord 2012;33:18-28.

172. Bachoud-Lévi A-C, Déglon N, Nguyen J-P, et al. Neuroprotective Gene Therapy for Huntington's Disease Using a Polymer Encapsulated BHK Cell Line Engineered to Secrete Human CNTF. Hum Gene Ther 2000;11:1723-1729.

173. Bloch J, Bachoud-Lévi AC, Déglon N, et al. Neuroprotective Gene Therapy for Huntington's Disease, Using Polymer-Encapsulated Cells Engineered to Secrete Human Ciliary Neurotrophic Factor: Results of a Phase I Study. Hum Gene Ther 2004;15:968-975. 
174. Aebischer P, Schluep M, Déglon N, et al. Intrathecal delivery of CNTF using encapsulated genetically modified xenogeneic cells in amyotrophic lateral sclerosis patients. Nat Med 1996;2:696-9.

175. Lathuilière A, Schneider BL. Un implant bioactif pour prévenir la maladie d'Alzheimer. médecine/sciences 2017;33:81-84.

176. Lathuilière A, Mach N, Schneider BL. Encapsulated cellular implants for recombinant protein delivery and therapeutic modulation of the immune system. Int J Mol Sci 2015;16:10578-600.

177. Yizhar O, Fenno LE, Davidson TJ, et al. Optogenetics in Neural Systems. Neuron 2011;71:9-34.

178. Han X, Chow BY, Zhou H, et al. A High-Light Sensitivity Optical Neural Silencer: Development and Application to Optogenetic Control of Non-Human Primate Cortex. Front Syst Neurosci 2011;5:18.

179. Galvan A, Stauffer WR, Acker L, et al. Nonhuman Primate Optogenetics: Recent Advances and Future Directions. J Neurosci 2017;37:10894-10903.

180. Han X, Qian X, Bernstein JG, et al. Millisecond-Timescale Optical Control of Neural Dynamics in the Nonhuman Primate Brain. Neuron 2009;62:191-198.

181. Gerits A, Vanduffel W. Optogenetics in primates: a shining future? Trends Genet 2013;29:403-411.

182. Yazdan-Shahmorad A, Diaz-Botia C, Hanson TL, et al. A Large-Scale Interface for Optogenetic Stimulation and Recording in Nonhuman Primates. Neuron 2016;89:927-939.

183. Ordaz J, Wu W, Xu X-M. Optogenetics and its application in neural degeneration and regeneration. Neural Regen Res 2017;12:1197.

184. Siddiqi F, Wolfe JH. Stem Cell Therapy for the Central Nervous System in Lysosomal Storage Diseases. Hum Gene Ther 2016;27:749-757.

185. Sun JM, Kurtzberg J. Cell therapy for diverse central nervous system disorders: inherited metabolic diseases and autism. Pediatr Res 2018;83:364-371.

186. Ghosh HS. Adult Neurogenesis and the Promise of Adult Neural Stem Cells. J Exp Neurosci 2019;13:117906951985687.

187. Nguyen $\mathrm{H}$, Zarriello $\mathrm{S}$, Coats $\mathrm{A}$, et al. Stem cell therapy for neurological disorders: A focus on aging. Neurobiol Dis 2019;126:85-104.

188. Rosenberg JB, Kaplitt MG, De BP, et al. AAVrh.10-Mediated APOE2 Central Nervous System Gene Therapy for APOE4-Associated Alzheimer's Disease. Hum Gene Ther Clin Dev 2018;29:24-47.

189. Ellinwood NM, Ausseil J, Desmaris N, et al. Safe, Efficient, and Reproducible Gene Therapy of the Brain in the Dog Models of Sanfilippo and Hurler Syndromes. Mol Ther 2011;19:251-259.

190. Sondhi D, Peterson DA, Giannaris EL, et al. AAV2-mediated CLN2 gene transfer to rodent and non-human primate brain results in long-term TPP-I expression compatible with therapy for LINCL. Gene Ther 2005;12:1618-1632.

191. Ciron C, Cressant A, Roux F, et al. Human $\alpha$-Iduronidase Gene Transfer Mediated by AdenoAssociated Virus Types 1, 2, and 5 in the Brain of Nonhuman Primates: Vector Diffusion and Biodistribution. Hum Gene Ther 2009;20:350-360.

192. Hadaczek P, Forsayeth J, Mirek H, et al. Transduction of Nonhuman Primate Brain with AdenoAssociated Virus Serotype 1: Vector Trafficking and Immune Response. Hum Gene Ther 2009;20:225-237.

193. Hadaczek P, Kohutnicka M, Krauze MT, et al. Convection-enhanced delivery of adenoassociated virus type 2 (AAV2) into the striatum and transport of AAV2 within monkey brain. Hum Gene Ther 2006;17:291-302.

194. Salegio EA, Kells AP, Richardson RM, et al. Magnetic resonance imaging-guided delivery of adeno-associated virus type 2 to the primate brain for the treatment of lysosomal storage disorders. Hum Gene Ther 2010;21:1093-1103.

195. Meneghini V, Lattanzi A, Tiradani L, et al. Pervasive supply of therapeutic lysosomal enzymes in the CNS of normal and Krabbe-affected non-human primates by intracerebral lentiviral gene therapy . EMBO Mol Med 2016;8:489-510. 
196. Naidoo J, Stanek LM, Ohno K, et al. Extensive Transduction and Enhanced Spread of a Modified AAV2 Capsid in the Non-human Primate CNS. Mol Ther 2018;26:2418-2430.

197. Bu J, Ashe KM, Bringas J, et al. Merits of Combination Cortical, Subcortical, and Cerebellar Injections for theTreatment of Niemann-Pick Disease Type A. Mol Ther 2012;20:1893.

198. Jarraya B, Boulet S, Scott Ralph G, et al. Dopamine Gene Therapy for Parkinson's Disease in a Nonhuman Primate Without Associated Dyskinesia. Sci Transl Med 2009;1:2ra4-2ra4.

199. Bucher T, Colle M-A, Wakeling E, et al. scAAV9 Intracisternal Delivery Results in Efficient Gene Transfer to the Central Nervous System of a Feline Model of Motor Neuron Disease. Hum Gene Ther 2013;24:670-682.

200. Naidoo J, Stanek LM, Ohno K, et al. Extensive Transduction and Enhanced Spread of a Modified AAV2 Capsid in the Non-human Primate CNS. Mol Ther 2018;26:2418-2430.

201. Ohno K, Samaranch L, Hadaczek P, et al. Kinetics and MR-Based Monitoring of AAV9 Vector Delivery into Cerebrospinal Fluid of Nonhuman Primates. Mol Ther - Methods Clin Dev 2019;13:47-54.

202. Gray SJ, Nagabhushan Kalburgi S, McCown TJ, et al. Global CNS gene delivery and evasion of anti-AAV-neutralizing antibodies by intrathecal AAV administration in non-human primates. Gene Ther 2013;20:450-9.

203. Taghian T, Marosfoi MG, Puri AS, et al. A Safe and Reliable Technique for CNS Delivery of AAV Vectors in the Cisterna Magna. Mol Ther 2020;28:411-421.

204. Wang H, Yang B, Qiu L, et al. Widespread spinal cord transduction by intrathecal injection of rAAV delivers efficacious RNAi therapy for amyotrophic lateral sclerosis. Hum Mol Genet 2014;23:668-681.

205. Choudhury SR, Fitzpatrick Z, Harris AF, et al. In Vivo Selection Yields AAV-B1 Capsid for Central Nervous System and Muscle Gene Therapy. Mol Ther 2016;24:1247-1257.

206. LeWitt PA, Rezai AR, Leehey MA, et al. AAV2-GAD gene therapy for advanced Parkinson's disease: a double-blind, sham-surgery controlled, randomised trial. Lancet Neurol 2011;10:309-319.

207. Christine CW, Starr PA, Larson PS, et al. Safety and tolerability of putaminal AADC gene therapy for Parkinson disease. Neurology 2009;73:1662-1669.

208. Marks WJ, Bartus RT, Siffert J, et al. Gene delivery of AAV2-neurturin for Parkinson's disease: a double-blind, randomised, controlled trial. Lancet Neurol 2010;9:1164-1172.

209. Souweidane MM, Fraser JF, Arkin LM, et al. Gene therapy for late infantile neuronal ceroid lipofuscinosis: neurosurgical considerations. J Neurosurg Pediatr 2010;6:115-122.

210. Tardieu $\mathrm{M}$, Zérah $\mathrm{M}$, Gougeon $\mathrm{ML}$, et al. Intracerebral gene therapy in children with mucopolysaccharidosis type IIIB syndrome: an uncontrolled phase $1 / 2$ clinical trial. Lancet Neurol . Epub ahead of print 2017. DOI: 10.1016/S1474-4422(17)30169-2.

211. Eberling JL, Jagust WJ, Christine CW, et al. Results from a phase I safety trial of hAADC gene therapy for Parkinson disease. Neurology 2008;70:1980-1983.

212. Muramatsu S, Fujimoto K, Kato S, et al. A Phase I Study of Aromatic L-Amino Acid Decarboxylase Gene Therapy for Parkinson's Disease. Mol Ther 2010;18:1731-1735.

213. Lewis $\mathrm{O}$, Woolley $\mathrm{M}$, Johnson $\mathrm{D}$, et al. Chronic, intermittent convection-enhanced delivery devices. J Neurosci Methods 2016;259:47-56.

214. Miranpuri G, Hinchman A, Wang A, et al. Convection Enhanced Delivery: A Comparison of infusion characteristics in ex vivo and in vivo non-human primate brain tissue. Ann Neurosci 2013;20:108-14.

215. Brady ML, Raghavan $R$, Singh $D$, et al. In vivo performance of a microfabricated catheter for intraparenchymal delivery. J Neurosci Methods 2014;229:76-83.

216. Gill T, Barua NU, Woolley M, et al. In vitro and in vivo testing of a novel recessed-step catheter for reflux-free convection-enhanced drug delivery to the brain. J Neurosci Methods 2013;219:1-9.

217. Lewis $\mathrm{O}$, Woolley $\mathrm{M}$, Johnson $\mathrm{DE}$, et al. Maximising coverage of brain structures using controlled reflux, convection-enhanced delivery and the recessed step catheter. J Neurosci 
Methods 2018;308:337-345.

218. Wernicke AG, Lazow SP, Taube S, et al. Surgical Technique and Clinically Relevant Resection Cavity Dynamics Following Implantation of Cesium-131 Brachytherapy in Patients With Brain Metastases. Oper Neurosurg 2016;12:49-60.

219. Singleton W, Collins A, Bienemann A, et al. Convection enhanced delivery of panobinostat (LBH589)-loaded pluronic nano-micelles prolongs survival in the F98 rat glioma model. Int J Nanomedicine 2017; Volume 12:1385-1399.

8

9 
1 Legends

2 Figure 1:

3 (A) Circulation of the CSF. Secretion by the choroid plexus and circulation within the ventricles

4 to the foramen of Magendie and Lushka (black arrows) to the extraventricular subarachnoid

5 spaces. Then circulation around the brain and the spinal cord (blue arrows), to the resorption

6 spaces (mainly the superior sagittal sinus)

7 (B) Intrathecal injection targeting the spinal cord

8 (C) Injection within the cisterna magna targeting the more superficial area of the brain (mainly

9 the cortical zone)

10 (D) Intraventricular injection targeting the deepest regions of the brain (mainly the basal 11 ganglia and the subventricular nucleus. Notice that the hippocampus region can be 12 theoretically reached by cisternal or intraventricular injection

13 (E) Following the CSF flow, a part of the vectors will reach the resorption areas and join the 14 cerebral blood stream and then the cerebral circulation to the peripheral organs

Figure 2: Intracerebral injection in NHP and humans

18 (A) Personal data of intracerebral gene therapy with 12 intracerebral delivery in white matter 19 for San Filippo A and MLD. (B) Neuronavigation software for preplanning. (C) Delivery 20 improvement with MRI Smartflow catheters; (D) Immediate Post-operative MRI and (E) Brain 21 delivery in NHP with the same MRI smartflow catheters. 
Figure 1:

2

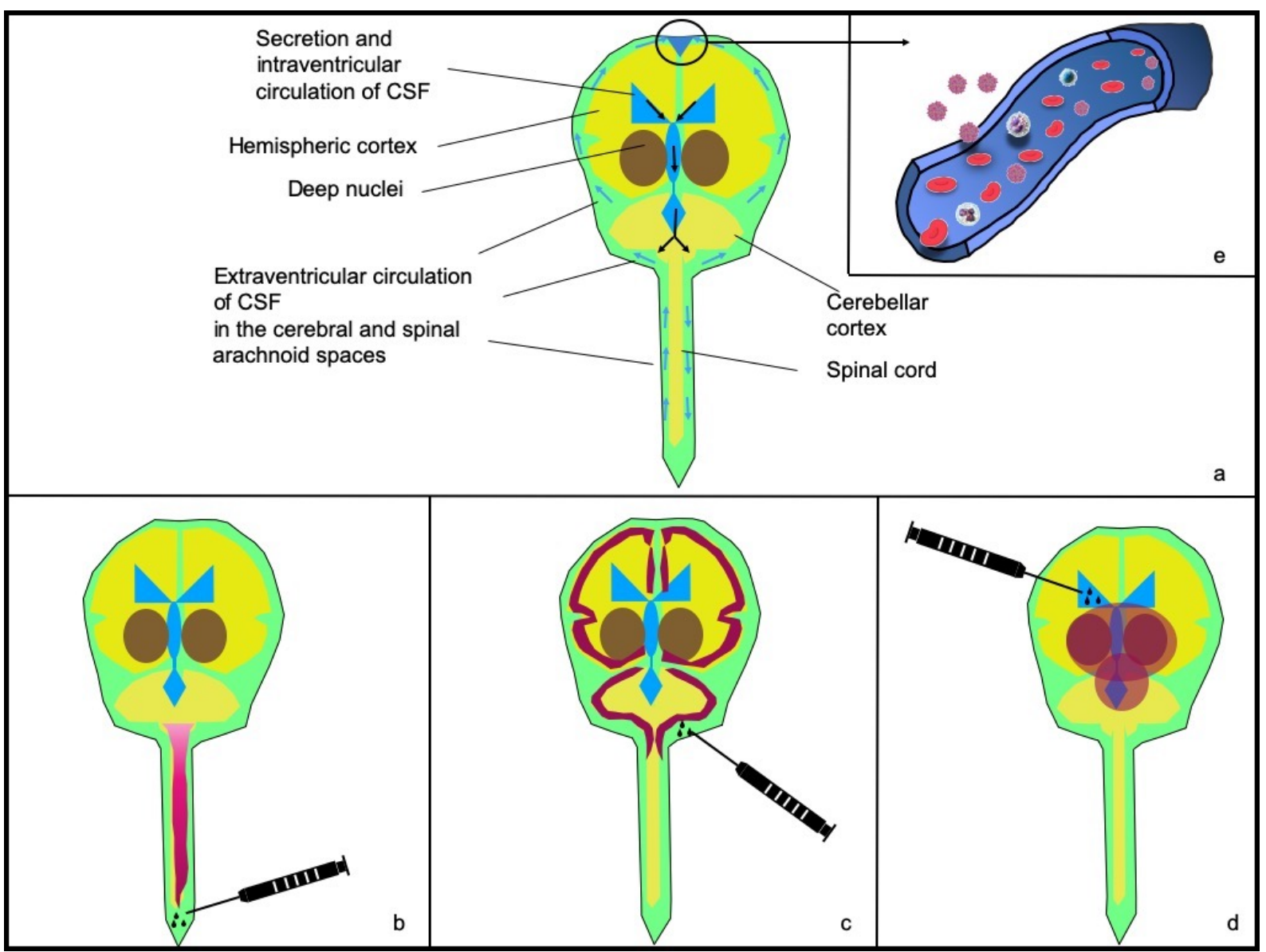


1 Figure 2: Intracerebral injection in NHP and humans
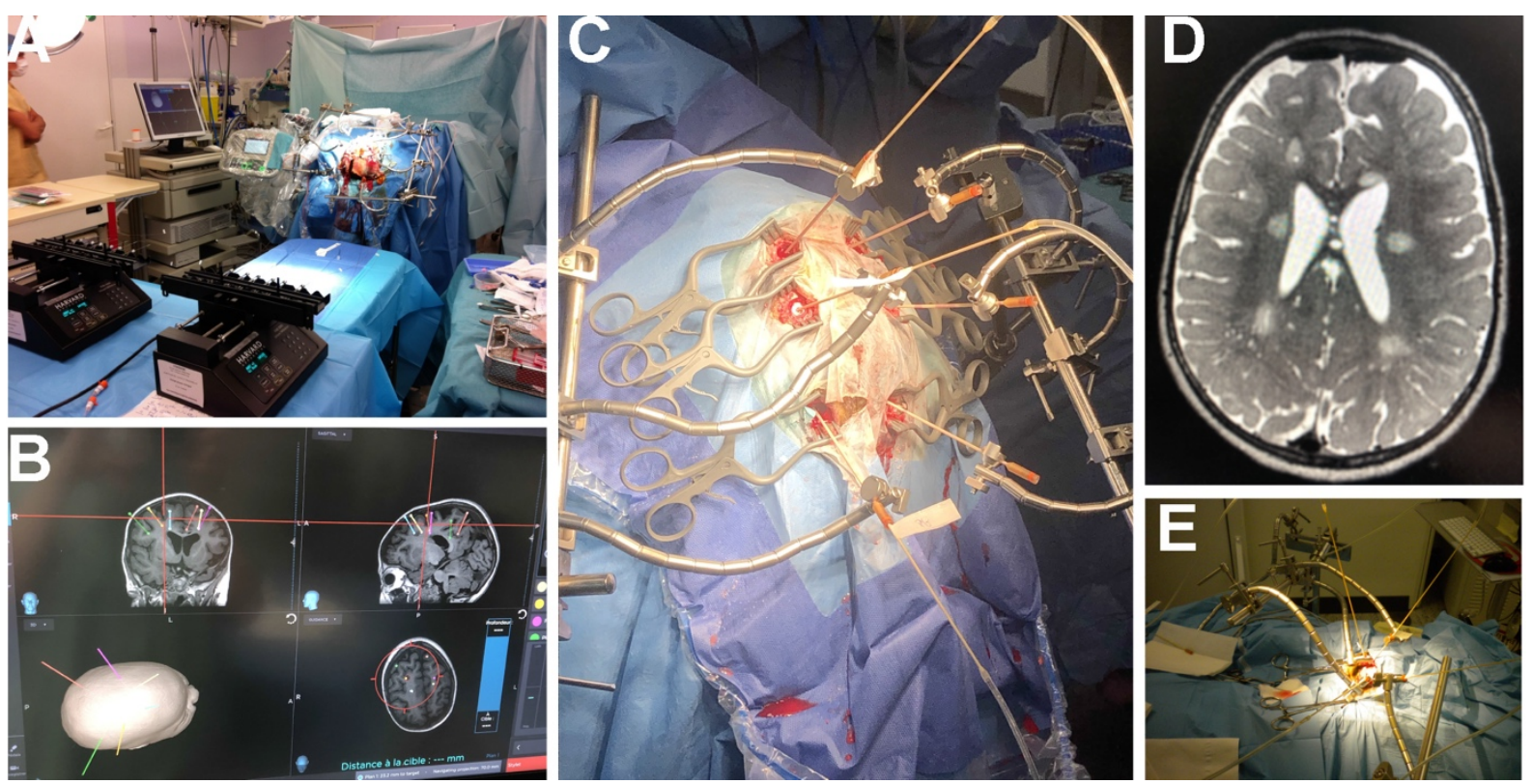
Table 1: Intraparenchymal delivery in large animal models

\begin{tabular}{|c|c|c|c|c|c|c|c|c|c|c|}
\hline $\begin{array}{l}\text { Transgene / } \\
\text { Pathology }\end{array}$ & Target & Specie & Age & Number & $\begin{array}{l}\text { Vector / } \\
\text { Buffer }\end{array}$ & Dose & Volume & Speed & Results & Article \\
\hline ARSA for MLD & $\begin{array}{l}3 \text { areas of the } \\
\text { centrum semiovale } \\
\text { white matter or in } \\
\text { the deep gray } \\
\text { nuclei (caudate } \\
\text { nucleus, putamen, } \\
\text { thalamus) }\end{array}$ & NHP & $\begin{array}{l}2-3 \text {-year- } \\
\text { old }\end{array}$ & 6 & $\operatorname{AAV} 2-5$ & $\begin{array}{l}1.9 .10^{12} \mathrm{vg} \text { to } \\
3.8 .10^{11} \mathrm{vg}\end{array}$ & $40 \mu \mathrm{l} /$ deposit & $3 \mu \mathrm{l} / \mathrm{min}$ & $\begin{array}{l}\text { AAV vector was detected in a brain volume of } 12-15 \mathrm{~cm} 3 \text { that corresponded to } 37-46 \% \text { of the injected } \\
\text { hemisphere. ARSA enzyme was expressed in multiple interconnected brain areas over a distance of } 22-33 \\
\mathrm{~mm} \text {. ARSA activity was increased by } 12-38 \% \text { in a brain volume that corresponded to } 50-65 \% \text { of injected } \\
\text { hemisphere }\end{array}$ & 37 \\
\hline GDNF for PD & $\begin{array}{l}\text { striatum, } \\
\text { substantia nigra, } \\
\text { caudate nucleus }\end{array}$ & $\begin{array}{l}\text { NHP, } \\
\text { rhesus }\end{array}$ & $\begin{array}{l}8 \text { aged } \\
(25 \text { years })+ \\
5 \text { young } \\
\text { adults }\end{array}$ & $8+5$ & $\begin{array}{l}\text { Lentiviral } \\
\text { vector }\end{array}$ & & & & $\begin{array}{l}\text { Extensive GDNF expression with anterograde and retrograde transport was seen in all animals. In aged } \\
\text { monkeys, lenti-GDNF augmented dopaminergic function. In MPTP-treated monkeys, lenti-GDNF reversed } \\
\text { functional deficits and completely prevented nigrostriatal degeneration. Additionally, lenti-GDNF injections to } \\
\text { intact rhesus monkeys revealed long-term gene expression (8 months). In MPTP-treated monkeys, lenti-GDNF } \\
\text { treatment reversed motor deficits in a hand-reach task }\end{array}$ & 78 \\
\hline $\begin{array}{l}\text { APOE2-HA for } \\
\text { AD }\end{array}$ & intrahippocampal & NHP & $\begin{array}{l}\text { 4- to } 7- \\
\text { year-old }\end{array}$ & 2 & $\begin{array}{l}\text { Recombinant } \\
\text { AAVrh.10 }\end{array}$ & $\begin{array}{l}5.10^{12} \mathrm{vg}(\mathrm{vg} ; 0.7- \\
1.2 .10^{12} \mathrm{vg} / \mathrm{kg}\end{array}$ & $\begin{array}{l}15 \mu \mathrm{L} \text { per } \\
\text { injection site }\end{array}$ & $1 \mu \mathrm{L} / \mathrm{min}$ & $\begin{array}{l}\text { AAVrh.10hAPOE2-HA directly into the hippocampus/entorhinal cortex achieved easily detectable, diffuse } \\
\text { ApoE2 expression in targeted regions using this route of delivery compared to the non-treated controls }\end{array}$ & 188 \\
\hline $\begin{array}{l}\text { NAGLU for } \\
\text { lysosomal } \\
\text { disease }\end{array}$ & white matter & dog & & 25 & $\begin{array}{l}\text { AAV2.5 AAV } \\
5.5\end{array}$ & $\begin{array}{l}5.10^{11} \mathrm{vg}, 1.5 .10^{12} \\
\mathrm{vg} / \mathrm{ml} ; 8.10^{12} \mathrm{vg} \\
2.5 .10^{12} \mathrm{vg} / \mathrm{ml} \\
20.10^{11} \mathrm{vg} \\
6.5 .10^{12} \mathrm{vg} / \mathrm{ml}\end{array}$ & $8 \times 40 \mu \mathrm{l}$ & $2 \mu \mathrm{L} / \mathrm{min})$ & $\begin{array}{l}\text { In immunosuppressed dogs, vector was efficiently delivered throughout the brain, induced } \alpha-\mathrm{N} \text {-acetyl- } \\
\text { glucosaminidase production, cleared stored compounds and storage lesions }\end{array}$ & 189 \\
\hline $\begin{array}{l}\text { CLN2 for Late } \\
\text { infantile } \\
\text { neuronal } \\
\text { ceroid } \\
\text { lipofusciosis }\end{array}$ & $\begin{array}{l}\text { head and body of } \\
\text { the caudate } \\
\text { nucleus, } \\
\text { hippocampus and } \\
\text { overlying cerebral } \\
\text { cortex }\end{array}$ & NHP & & & AAV 2 & $3.6 \times 10^{11} \mathrm{pu}$ & $180 \mu \mathrm{l}$ & $1 \mu \mathrm{l} / \mathrm{min}$ & $\begin{array}{l}\text { Assessment at } 5 \text { and } 13 \text { weeks demonstrated widespread detection of TPP-I in neurons, but not glial cells, at } \\
\text { all regions of injection. The distribution of TPP--1-positive cells was similar between the two time points at all } \\
\text { injection sites }\end{array}$ & 190 \\
\hline$\alpha$-iduronidase & $\begin{array}{l}\text { putamen and } \\
\text { centrum semiovale }\end{array}$ & NHP & & 6 & $\begin{array}{l}\text { (rAAV2/1, } \\
\text { rAAV2 } 2 / 2 \\
\text { and } \mathrm{rAAV} 2 / 5\end{array}$ & $1.4 .10^{10} \mathrm{vg}$ & $2 \times 50 \mu \mathrm{l}$ & & $\begin{array}{l}\text { global diffusion throughout the brain was not significantly different between the three serotypes. However, } \\
\text { rAAV2/1 and rAAV2/5 resulted in higher vector copy numbers per cell than did rAAV2/2, respectively, in the } \\
\text { brain and the distal neuronal structures }\end{array}$ & 191 \\
\hline CMV-hrGFP & $\begin{array}{l}\text { corona radiata, } \\
\text { striatum, and basal } \\
\quad \text { forebrain }\end{array}$ & $\begin{array}{l}\mathrm{NHP} \\
\text { cynomo } \\
\text { Igus }\end{array}$ & & 8 & AAV1 & 2.3 to $6.910^{11} \mathrm{vg}$ & 10 to $150 \mu \mathrm{l}$ & 0.2 to $3 \mu / / \mathrm{min}$ & $\begin{array}{l}\text { AAV1 is actively trafficked to regions distal from the infusion site. In addition to neuronal transduction, a } \\
\text { significant nonneuronal cell population was transduced by AAV1 vector }\end{array}$ & 192 \\
\hline $\begin{array}{l}\text { AAV-TK,AAV2- } \\
\text { AADC }\end{array}$ & & NHP & & & AAV2 & & & & at least $75 \%$ of the putamen could be covered by a single infusion of the vector & 193 \\
\hline $\begin{array}{l}\text { human acidic } \\
\text { sphingomyelin } \\
\text { ase For } \\
\text { Nieman Pick } \\
\text { disease }\end{array}$ & $\begin{array}{l}\text { brainstem (1 site) } \\
\text { and thalamus } \\
\text { (bilateral) }\end{array}$ & NHP & & 4 & AAV2 & $1.10^{12} \mathrm{vg} / \mathrm{ml}$ & 33 to $199 \mu \mathrm{l}$ & $\begin{array}{l}0,1 \text { increased } \\
\text { at } 10 \text {-min } \\
\text { intervals to } \\
0.2,0.5,0.8 \\
1.0, \text { and } \\
2.0 \mu \mathrm{\mu l} / \mathrm{min}\end{array}$ & $\begin{array}{l}\text { We found that enzymatic augmentation in brainstem, thalamic, cortical, as well subcortical areas provided } \\
\text { convincing evidence that much of the large NHP brain can be transduced with as few as three injection sites. }\end{array}$ & 194 \\
\hline hARSA & $\begin{array}{l}\text { external capsule } \\
\text { and thalamus }\end{array}$ & NHP & 2-3 months & 9 & Lentivirus & $\begin{array}{l}5.10^{7} \text { TU/injection } \\
\text { site }\end{array}$ & $80 \mu \mathrm{l}$ & NA & $\begin{array}{l}\text { favorable safety profile and consistent pattern of LV transduction and enzyme biodistribution. Efficient gene } \\
\text { transfer in neurons, astrocytes, and oligodendrocytes close to the injection sites resulted in robust production } \\
\text { and extensive spreading of transgenic enzymes in the whole CNS }\end{array}$ & 195 \\
\hline$\frac{\text { heparan }}{\text { sulfate }}$ & thalamus + ICV & NHP & & & AAV2 & & & & $\begin{array}{l}\text { The combination of thalamic and intracerebroventricular delivery resulted in transduction of } \\
\text { oligodendrocytes in superficial cortical layers and neurons in deeper cortical layers }\end{array}$ & 196 \\
\hline
\end{tabular}




\begin{tabular}{|c|c|c|c|c|c|c|c|c|c|c|}
\hline \multicolumn{11}{|l|}{$\frac{\text { proteoglycan }}{\underline{\text { receptor }}}$} \\
\hline hARSA & $\begin{array}{l}\text { White matter, } 6 \\
\text { sites }\end{array}$ & NHP & & 14 & AAVrh10 & $\begin{array}{l}5.5 .10^{11} \\
\mathrm{vg} / \text { hemisphere }\end{array}$ & $\begin{array}{l}30 \text { II for each } \\
\text { deposit, } 0.5 \\
\text { II/min }\end{array}$ & $0.5 \mathrm{I} / \mathrm{min}$ & $\begin{array}{l}\text { After injection of the 1 - dose, AAVrh.10- hARSA vector was detected in a large part of the injected } \\
\text { hemisphere, while ARSA activity exceeded the normal endogenous activity level by 14-31\% }\end{array}$ & 11 \\
\hline hASM for NP-A & $\begin{array}{l}12 \text { sites : motor } \\
\text { cortex, occipital } \\
\text { cortex, striatum } \\
\text { and thalamus, } \\
\text { hippocampus, } \\
\text { cerebellum }\end{array}$ & NHP & $2 \mathrm{Y} / \mathrm{o}$ & 2 & AAV1 & 2.6. $10^{12} \mathrm{gc}$ & $520 \mu \mathrm{l}$ total & NA & $\begin{array}{l}\text { a combination cortical, subcortical, and cerebellar injection protocol could provide therapeutic levels of hASM } \\
\text { to regions of the NHP brain }\end{array}$ & 197 \\
\hline ARSA & $\begin{array}{l}6 \text { sites deep gray } \\
\text { matter + white } \\
\text { matter }\end{array}$ & NHP & $\begin{array}{l}\text { 3- to } 6- \\
\text { year-old }\end{array}$ & 11 & AAVrh.10 & $1.5 .10^{12} \mathrm{vg}$ & 50- $\mu \mathrm{l} /$ deposit & $1-3 \mathrm{microl} / \mathrm{min}$ & $\begin{array}{l}\text { Of the five routes studied, administration to the white matter generated the broadest distribution of ARSA, } \\
\text { with } 80 \% \text { of the brain displaying more than a therapeutic (10\%) increase in ARSA activity above PBS controls }\end{array}$ & 85 \\
\hline SGSH & $\begin{array}{l}\text { Subcortical white } \\
\text { matter }\end{array}$ & Dogs & & 3 & AAVrh.10 & $\begin{array}{l}\text { 1. } 10^{12} \mathrm{vg} \text { and } 2 \text {. } \\
10^{12} \mathrm{vg}\end{array}$ & $\begin{array}{l}500 \mu l / \text { deposit } \\
\quad(2 \text { or } 4 \\
\text { deposits) }\end{array}$ & $10 \mathrm{ul} / \mathrm{min}$ & $\begin{array}{l}\text { extensive distribution into both rostral and caudal brain regions. significant amounts of vector DNA were } \\
\text { found in only } 37 \% \text { of brain punches, increases of SGSH activity of } 20 \% \text { or greater relative to vehicle-treated } \\
\text { animals were found in } 78 \% \text { of the brain punches tested } 4 \text { weeks after injection. }\end{array}$ & 77 \\
\hline \multirow[t]{2}{*}{ SGSH } & $\begin{array}{l}\text { Subcocrtical white } \\
\text { matter }\end{array}$ & NHP & 4 years & 2 & AAVrh.10 & 7.2. $10^{11} \mathrm{vg}$ & $\begin{array}{l}50 \mu 1 / \text { deposit ( } \\
4 \text { deposits) }\end{array}$ & $5 \mathrm{ul} / \mathrm{min}$ & $\begin{array}{l}\text { presence of vector DNA in a limited proportion (11\%) of brain punches, but a wide distribution of SGSH } \\
\text { enzymatic activity of } 20 \% \text { or more of control levels in the near totality (97\%) of the NHP brain } 6 \text { weeks after } \\
\text { injection. }\end{array}$ & 77 \\
\hline & striatum & NHP & & & $\begin{array}{l}\text { tricistronic } \\
\text { lentiviral } \\
\text { vector }\end{array}$ & & & & $\begin{array}{l}\text { restoration of extracellular concentrations of dopamine and corrected the motor deficits for } 12 \text { months } \\
\text { without associated dyskinesias }\end{array}$ & 198 \\
\hline
\end{tabular}




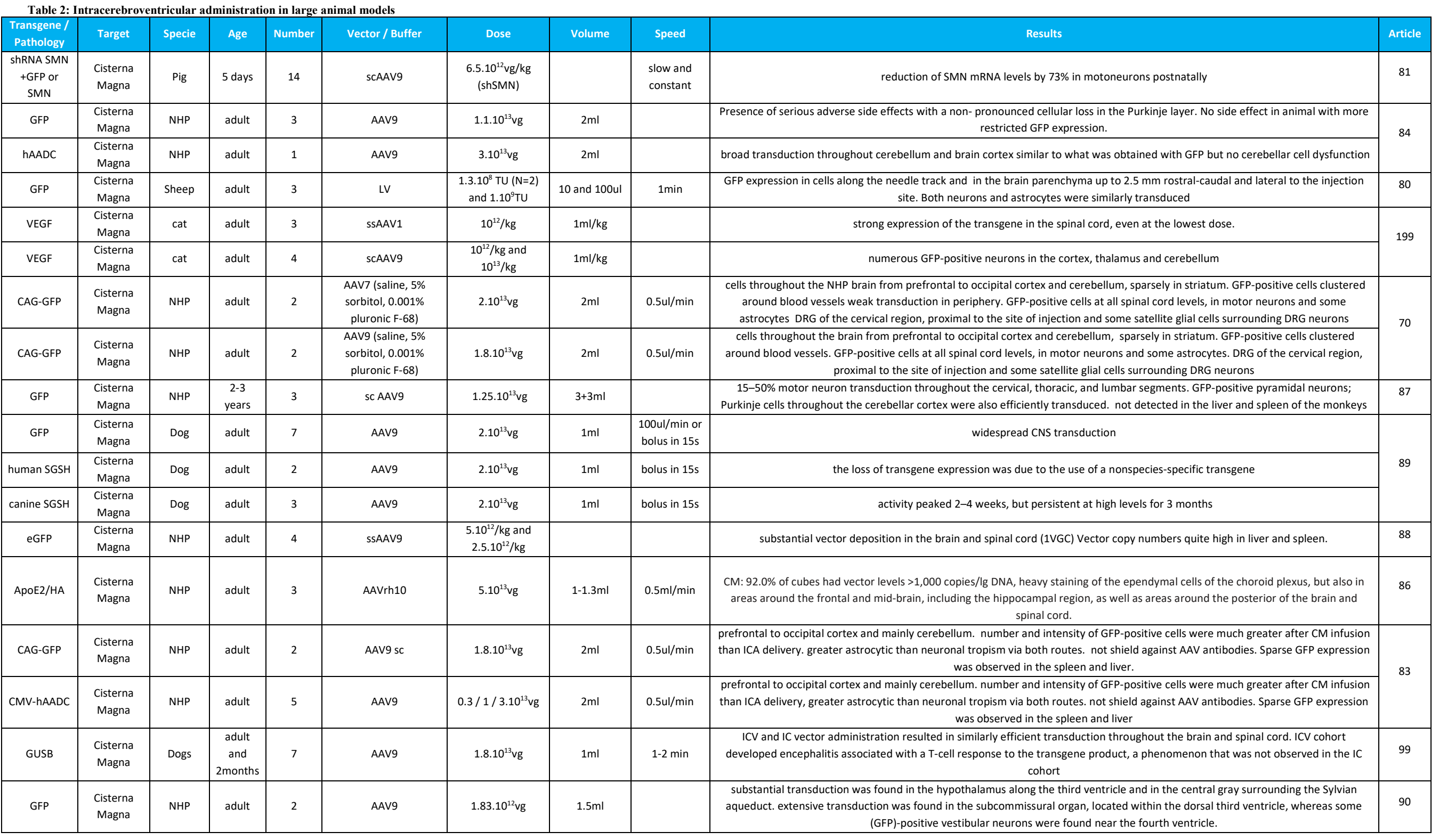




\begin{tabular}{|c|c|c|c|c|c|c|c|c|c|c|}
\hline GFP & $\begin{array}{l}\text { Cisterna } \\
\text { Magna }\end{array}$ & NHP & adult & 2 & AAV2,5 & $2.10^{12} \mathrm{vg}$ & $1.5 \mathrm{ml}$ & & very strong transduction of the ependymal structure & \\
\hline GFP & $\begin{array}{l}\text { Cisterna } \\
\text { Magna }\end{array}$ & Cat & 50 days & 6 & scAAV9 & $10^{12} \mathrm{vg} / \mathrm{kg}$ & $1-1,5 \mathrm{ml}$ & & $\begin{array}{l}\text { more efficiently targeting of MNs of the lumbar (99\%) than of the cervical regions ( } 84 \%) \text { spinal cord. numerous oligodendrocytes } \\
\text { were also transduced in the brain and in the spinal cord white matter of young cats, but not of neonates }\end{array}$ & 92 \\
\hline $\begin{array}{l}\text { CAG-ARSA- } \\
\text { FLAG / MLD }\end{array}$ & $\begin{array}{c}\text { lateral } \\
\text { ventricle }\end{array}$ & NHP & adult & 2 & AAVrh10 in PBS & $1,5.10^{12} \mathrm{vg}$ & $75 \mathrm{ul}$ & $15 \mathrm{ul} / \mathrm{min}$ & almost no copies and no ARSA expression $(11 / 83=13 \%)$ whereas gold standard: white matter $82 \%$ & 85 \\
\hline ApoE2/HA & $\begin{array}{l}\text { left or right } \\
\text { ventricle }\end{array}$ & NHP & adult & 3 & AAVrh10 & $5.10^{13} \mathrm{vg}$ & $1-1.3 \mathrm{ml}$ & $0.2 \mathrm{ml} / \mathrm{min}$ & $\begin{array}{l}\text { ICV: } 90.0 \% \text { of cubes had vector levels }>1,000 \text { copies/Ig DNA, heavy staining of the ependymal cells of the choroid plexus, but also in } \\
\text { areas around the frontal and mid-brain, including the hippocampal region, as well as areas around the posterior of the brain and } \\
\text { spinal cord. }\end{array}$ & 86 \\
\hline $\begin{array}{l}\text { CAG-TPP1 } \\
\text { /CLN2 }\end{array}$ & $\begin{array}{l}\text { lateral } \\
\text { ventricles } \\
+/-\mathrm{CM}\end{array}$ & $\begin{array}{l}\text { Dog (TPP } \\
\text { deficient) }\end{array}$ & $\begin{array}{c}10-11 \\
\text { days }\end{array}$ & 7 & AAV2 & $1.1 .10^{12} \mathrm{vg}$ & $1,5 \mathrm{ml}$ & & TPP 1 activity in CSF detectable at 5 days but no more detectable at 2 months & 82 \\
\hline IDUA / MPS I & suboccipital & Cat & adult & 5 & AAV9 & $10^{12} \mathrm{vg} / \mathrm{kg}$ & $1-2 \mathrm{ml}$ & bolus & $\begin{array}{l}\text { complete correction of biochemical and histological manifestations throughout the CNS. antibody responses against IDUA which } \\
\text { reduced detectable enzyme without substantially reducing efficacy. no evidence of toxicity }\end{array}$ & 88 \\
\hline GFP & ICV & Dog & adult & 2 & AAVg & $2.10^{13} \mathrm{vg}$ & $1 \mathrm{ml}$ & bolus in $15 \mathrm{~s}$ & Comparable with CM administration & 89 \\
\hline GFP & ICV & NHP & & & AAV2 - HBKO & $1.8 .10^{13 \mathrm{vg}}$ & $1.5 \mathrm{ml}$ & $1-10 \mathrm{ul} / \mathrm{min}$ & $\begin{array}{l}\text { widespread cortical transduction, with oligodendrocytes transduced. Robust motor neuron transduction observed in all levels of the } \\
\text { spinal cord }\end{array}$ & 200 \\
\hline hASM-HA & CM & NHP & adult & 6 & AAV9 & $1.32 .10^{13} \mathrm{vg}$ & $6 \mathrm{ml}$ & $\begin{array}{l}1 \mathrm{ml} / \mathrm{min} \\
(\mathrm{n}=3) \text { or } \\
1 \mathrm{ml} / \mathrm{h}(\mathrm{n}=3)\end{array}$ & Infusion of the vector in brain and spinal cord after MRI but only with High speed delivery & 201 \\
\hline hASM-HA & ICV & NHP & adult & 2 & AAV9 & $1.32 .10^{13} \mathrm{vg}$ & $6 \mathrm{ml}$ & $\begin{array}{l}1 \mathrm{ml} / \mathrm{min} \\
(\mathrm{n}=3) \text { or } \\
1 \mathrm{ml} / \mathrm{h}(\mathrm{n}=3)\end{array}$ & $\begin{array}{l}\text { much larger cortical distribution at the end of the acquisitions, including occipital cortical regions that were not covered by any other } \\
\text { routes of delivery }\end{array}$ & 201 \\
\hline CIDUA & Suboccipital & Dogs & 28 days & 3 & AAVg & $10^{12} \mathrm{vg} / \mathrm{kg}$ & $0.5 \mathrm{ml}$ & bolus & vector distributed throughout the CNS. supraphysiologic expression of IDUA in CSF, which declined to the normal range & 94 \\
\hline
\end{tabular}




\begin{tabular}{|c|c|c|c|c|c|c|c|c|c|c|}
\hline $\begin{array}{l}\text { Transgene / } \\
\text { Pathology }\end{array}$ & Target & Specie & Age & Number & $\begin{array}{l}\text { Vector } / \\
\text { Buffer }\end{array}$ & Dose & Volume & Speed & Results & Article \\
\hline GUSB / MPS VII & IT & Dog & $\begin{array}{c}18-20 \\
\text { days }\end{array}$ & 3 & AAvg & $5.10^{12} \mathrm{vg} / \mathrm{kg}$ & $1-2 \mathrm{ml}$ & $1-2 \min$ & 50-fold higher expression and a more profound effect on markers of disease than IV delivery & \multirow{2}{*}{93} \\
\hline GUSB / MPS VII & IT & Dog & $\begin{array}{c}18-20 \\
\text { days }\end{array}$ & 2 & AAV10 & $5.10^{12} \mathrm{vg} / \mathrm{kg}$ & $1-2 \mathrm{ml}$ & $1-2 \min$ & $\sim 50$-fold higher expression and a more profound effect on markers of disease than IV delivery & \\
\hline GUSB & Lumbar L4/L5 & NHP & adult & 6 & AAvg & $2.10^{13} \mathrm{vg}$ & $5 \mathrm{ml}$ & & transduction efficiency was not improved by placing animals in the Trendelenburg position after injection. & 99 \\
\hline GFP & Lumbar citern & NHP & adult & 8 & AAV9 & $\begin{array}{l}\text { 1.83.1.12 } \mathrm{vg}(\mathrm{N}=6) \text { and } \\
5.5 \cdot 10^{12} \mathrm{vg}(\mathrm{N}=2)\end{array}$ & $1 \mathrm{ml}$ & & very strong transduction of the ependymal structure & 202 \\
\hline GFP & L4/L5 & NHP & adult & 7 & scAAVg & $1.10^{13 \mathrm{vg} / \mathrm{kg}}$ & $1 \mathrm{ml}$ & Bolus & $\begin{array}{l}73 \% \text { of motor neurons targeted in the lumbar region, } 53 \% \text { of motor neurons targeted in thoracic region, and } 29 \% \text { in the } \\
\text { cervical spinal cord; tilting for } 10 \text { minutes was sufficient to increase motor neuron transduction to } 55,62 \text {, and } 80 \% \text { in the } \\
\text { cervical, thoracic, and lumbar region. GFP in all brain regions with particularly strong signals in the hippocampus and in } \\
\text { the motor cortex. In the brainstem, high transduction of the hypoglossal and trigeminal nuclei, with more than } 60 \text { and } \\
75 \% \text { motor neurons.In the cerebellum, both Purkinje cells and cells of the nuclear layer demonstrated high GFP } \\
\text { expression }\end{array}$ & 13 \\
\hline $\begin{array}{l}\text { miRNA anti } \\
\text { SOD1 }\end{array}$ & $\mathrm{L} 5$ and cathether & NHP & adult & 32 & AAV10 & & $2.5 \mathrm{ml}$ & $7.5 \mathrm{ml} /$ hour & $\begin{array}{l}\text { preimplantation of a catheter and placement of the subject with head down at } 30^{\circ} \text { during intrathecal infusion. efficient } \\
\text { delivery and effective silencing of the SOD } 1 \text { gene in motor neurons }\end{array}$ & 98 \\
\hline GFP & L5/L6 & Pig & 5 days & 1 & AAvg & $5.2 .10^{12} \mathrm{vg} / \mathrm{kg}$ & $0.25 \mathrm{ml}$ & bolus & $\begin{array}{l}\text { Extensive motor neuron transduction at all levels of the spinal cord. The brain regions with the highest levels of GFP } \\
\text { expression were cerebellar Purkinje cells, nerve fibers within the medulla as well as discrete nuclei, such as the olivary } \\
\text { nucleus. Expression within the rest of the brain was restricted to scattered cells near the meningeal surfaces. No obvious } \\
\text { expression in periphery }\end{array}$ & 96 \\
\hline $\begin{array}{l}\text { miRNA anti } \\
\text { SOD1 }\end{array}$ & Lumbar & $\begin{array}{c}\text { Marmo } \\
\text { sets }\end{array}$ & $\begin{array}{l}\text { less } \\
\text { than } 4 \\
\text { years }\end{array}$ & 9 & AAV10 & $6.10^{12} \mathrm{vg} / \mathrm{kg}$ & $300 u l$ & bolus & $\begin{array}{l}\text { high transduction of lumbar spinal cord, than thoracic and cervical. High liver transduction. In brain, mild to good } \\
\text { transduction, depending on the regions. Robust GFP staining was seen at the injection site at LSC level all the way to CSC } \\
\text { level. }\end{array}$ & 95 \\
\hline GFP & L5 with cathethers & Pigs & $\begin{array}{c}2 \\
\text { months }\end{array}$ & 2 & scAAvg & $3 \times 1.10^{12} \mathrm{vg}$ & $3 \times 0.5 \mathrm{ml}$ & Bolus & $\begin{array}{c}\text { GFP expression in 10-30\% of the motor neurons, and one segment (L2) showed GFP expression in } 35 \% \text { of the motor } \\
\text { neurons. }\end{array}$ & 87 \\
\hline eGFP & Lumbar punctura & NHP & adult & 2 & ssAAV9 & $2.5 .10^{12} / \mathrm{kg}$ & & & $\begin{array}{l}\text { 10x lower gene transfer throughout the spinal cord, and up to } 100-\text {-fold less in the brain compare to } \mathrm{CM} \text {. Vector copy } \\
\text { numbers quite high in liver and spleen. }\end{array}$ & 88 \\
\hline hASM-HA & Lumbar & NHP & adult & 3 & scAAvg & $1.32 .10^{13 \mathrm{vg}}$ & $6 \mathrm{ml}$ & $\begin{array}{c}1 \mathrm{ml} / \mathrm{min} \text { or } \\
1 \mathrm{ml} / \mathrm{hour}\end{array}$ & Leakage of the infusion in musculature & 201 \\
\hline GFP & Lumbar & Sheep & adult & 2 & scAAVg & & $15 \mathrm{ml}$ & $1 \mathrm{ml} / \mathrm{min}$ & $\begin{array}{l}\text { the frontal, occipital, and parietal cortices exhibited extensive neuronal and glial cell transduction, whereas in the motor } \\
\text { cortex glial transduction was primarily observed. Scarce positive neurons were present in the caudate, putamen, and } \\
\text { thalamus.Strong GFP staining was noted in the cerebellum, including Purkinje cells, deep cerebellar nuclei and adjacent }\end{array}$ & 203 \\
\hline
\end{tabular}




\begin{tabular}{|c|c|c|c|c|c|c|c|c|c|c|}
\hline & & & & & & & & & $\begin{array}{l}\text { axons in the white matter, cerebellar peduncles, and brainstem. Robust neuronal transduction was observed along the } \\
\text { entire length of the spinal cord, from cervical to lumbar }\end{array}$ & \\
\hline $\begin{array}{l}\text { miRNA anto } \\
\text { SOD1 }\end{array}$ & Lumbar L4/L5 & $\begin{array}{c}\text { Marmo } \\
\text { set }\end{array}$ & adult & 1 & AAV10 & $2.7 .10^{12} \mathrm{vg}$ & 250ul & slow bolus & robust expression in motor neurons along the full length of the spinal cord & 204 \\
\hline
\end{tabular}

Table 4 : Intravenous administration in large animal models

\begin{tabular}{|c|c|c|c|c|c|c|c|c|c|c|}
\hline $\begin{array}{l}\text { Transgene / } \\
\text { Pathology }\end{array}$ & Target & Specie & Age & Number & $\begin{array}{l}\text { Vector / } \\
\text { Buffer }\end{array}$ & Dose & Volume & Speed & Results & Article \\
\hline CAG-GFP & $\begin{array}{l}\text { Internal carotid } \\
\text { artery }\end{array}$ & NHP & & 3 & AAV9 sc & $3.10^{13} \mathrm{vg}$ & $\begin{array}{c}11 / 21 / \\
40 \mathrm{ml}\end{array}$ & $4 \mathrm{ml} / \mathrm{min}$ & $\begin{array}{l}\text { broader transgene distribution throughout the CNS, extending through several cortical regions. Scattered } \\
\text { GFP-expressing cells were found from the pre- frontal to occipital cortex, and in the cerebellum. } \\
\text { widespread peripheral organ transduction (Liver and Spleen) }\end{array}$ & 83 \\
\hline $\begin{array}{l}\text { CAG-ARSA- } \\
\text { FLAG / MLD }\end{array}$ & $\begin{array}{l}\text { Intra-arterial (right } \\
\text { middle cerebral } \\
\text { artery) }\end{array}$ & NHP & adult & 1 & $\begin{array}{l}\text { AAVrh10 } \\
\text { in PBS }\end{array}$ & $1,5 \cdot 10^{12} \mathrm{vg}$ & $12 \mathrm{ml}$ & bolus & almost no copies and no ARSA expression $(6 / 77=7,8 \%)$ whereas gold standard: white matter $82 \%$ & 85 \\
\hline $\begin{array}{c}\text { GUSB / MPS } \\
\text { VII }\end{array}$ & IV & Dog & 3 days & 1 & AAV9 & $2.10^{13} \mathrm{vg} / \mathrm{kg}$ & $1-2 \mathrm{ml}$ & $1-2 \mathrm{~min}$ & $\begin{array}{l}\text { limited GUSB expression in cortical and hippocampal neurons, and Purkinje cells, while average expression } \\
\text { levels in other brain tissues were only } 1 \text { to } 6 \% \text { of normal levels Similar to AAV10 injected animals. Clear } \\
\text { motoneurons transduction }\end{array}$ & \multirow[t]{2}{*}{93} \\
\hline $\begin{array}{c}\text { GUSB / MPS } \\
\text { VII }\end{array}$ & IV & Dog & 3 days & 1 & AAV10 & $2.10^{13} \mathrm{vg} / \mathrm{kg}$ & $1-2 \mathrm{ml}$ & $1-2 \mathrm{~min}$ & $\begin{array}{l}\text { limited GUSB expression in cortical and hippocampal neurons, and Purkinje cells, while average expression } \\
\text { levels in other brain tissues were only } 1 \text { to } 6 \% \text { of normal levels Similar to AAV9 injected animals. Clear } \\
\text { motoneurons transduction }\end{array}$ & \\
\hline NAGLU & IV & NHP & adult & 8 & ssAAVg & $\begin{array}{c}1(\mathrm{~N}=2) \text { or } 2.10^{13} \mathrm{vg} / \mathrm{kg} \\
(\mathrm{N}=4)\end{array}$ & $5 \mathrm{ml}$ & bolus & $\begin{array}{l}\text { global CNS and broad somatic transduction. evident vector transduction throughout the brain. Low levels } \\
\text { of preexisting anti-AAV9 antibodies did not diminish vector transduction but high-level of preexisting anti- } \\
\text { AAV9 Abs lead to reduced transduction in liver and other somatic tissues, but had no detectable impact on } \\
\text { transgene expression in the brain. }\end{array}$ & 40 \\
\hline GFP & carotid artery & Cat & 2 months & 1 & AAV-B1 & $3.4 .10^{12} \mathrm{vg}$ & & Bolus & $\begin{array}{l}\text { sparse but widespread neuronal gene transfer throughout the brain. AAV-B1 transduced neurons in the } \\
\text { cerebral cortex, striatum, hippocampus, thalamus and Purkinje neurons in the cerebellum and motor } \\
\text { neurons throughout the midbrain. no indication that AAV-B1 transduced endothelial cells. negligible } \\
\text { transduction of liver was observed with AAV-B1, while strong gene transfer to skeletal and cardiac muscle } \\
\text { could be detected }\end{array}$ & 205 \\
\hline VEGF & jugular vein & Cat & 2 days & 3 & scAAv9 & $10^{12} \mathrm{vg} / \mathrm{kg}$ & $1 \mathrm{ml} / \mathrm{kg}$ & bolus & no detectable protein & 92 \\
\hline GFP & jugular vein & Cat LIX1 & 7 days & 2 & scAAVg & $1.5 .10^{12} \mathrm{vg}$ & $1 \mathrm{ml}$ & Bolus & $\begin{array}{l}\text { GFP was detected from the cervical part of the spinal cord to the cauda equina in a number of cells in the } \\
\text { ventral spinal cord. In neonates, up to } 39 \text { and } 34 \% \text { of the MNs. Nerve fibers of the fasciculi gracilis and } \\
\text { cuneatus dorsal sensory tracts also contained large amounts of GFP. }\end{array}$ & 91 \\
\hline GFP & jugular vein & Cat LIX1 & 7 weeks & 2 & scAAV9 & 1.2.10 $10^{12} \mathrm{vg}$ & $3.6 \mathrm{ml}$ & $\begin{array}{l}\text { Bolus } \\
\end{array}$ & up to $15 \%$ of MNs transduction observed & \\
\hline CIDUA & jugular vein & Dogs & 90 days & 4 & AAV8 & $3.10^{12} \mathrm{vg} / \mathrm{kg}$ & $0.5-1 \mathrm{ml}$ & bolus & mild in serum IDUA activity & 94 \\
\hline GFP & $\begin{array}{c}\text { saphenous or } \\
\text { intracarotid }\end{array}$ & NHP & adult & 4 & sc AAVg & $0.9-1.10^{13} \mathrm{vg} / \mathrm{kg}$ & $10 \mathrm{ml} / \mathrm{kg}$ & $2.5 \mathrm{ml} / \mathrm{min}$ & predominant transduction of glia in NHPs after both intravenous and intra-arterial administration & 90 \\
\hline
\end{tabular}




\begin{tabular}{|c|c|c|c|c|c|c|c|c|c|c|}
\hline VEGF & jugular vein & cat & adult & 6 & scAAV9 & $\begin{array}{l}10^{12} / \mathrm{kg}(\mathrm{N}=2) \text { and } 10^{13} / \mathrm{kg} \\
(\mathrm{N}=4)\end{array}$ & $1-2 \mathrm{ml}$ & & $\begin{array}{l}\text { transduction of the spinal cord occurs in neonatal and adult cats but the level of transgene expression } \\
\text { remained low in both adult and neonate-injected animals. transduction was detected essentially in liver. }\end{array}$ & 199 \\
\hline GFP & saphenous vein & NHP & adult & 1 & AAVg & $1-3.10^{14} \mathrm{vg} / \mathrm{kg}$ & & bolus & $\begin{array}{l}\text { only MN and and cells with glial morphology that were sparsely scattered. most abundant number of GFP- } \\
\text { expressing cells in all cortical regions lateral geniculate midbrain, pons and medulla. Subcortical structures } \\
\text { such as thalamus and putamen were also GFP+ but at a lower cell density. mostly glial transduction with } \\
\text { microglia and astrocytes.high levels of vector in liver and also other peripheral tissues }\end{array}$ & \multirow{2}{*}{96} \\
\hline GFP & $\begin{array}{l}\text { cathether through } \\
\text { the brachial artery } \\
\text { until aorta }\end{array}$ & NHP & adult & 1 & AAV9 & $2.7 .10^{13} \mathrm{vg} / \mathrm{kg}$ & & bolus & $\begin{array}{l}\text { Motor neuron targeting extensive transgene expression throughout the entire brain. most abundant } \\
\text { number of GFP-expressing cells in all cortical regions lateral geniculate, midbrain, pons and medulla. } \\
\text { Subcortical structures such as thalamus and putamen were also GFP+ but at a lower cell density. glial } \\
\text { transduction with microglia and astrocytes. Liver, heart, testis and largely peripheral transduction }\end{array}$ & \\
\hline IDUA & IV & NHP & adult & 2 & AAV9 & $2.5 .10^{13} \mathrm{vg} / \mathrm{kg} 7.5 .10^{13} \mathrm{vg} / \mathrm{kg}$ & $1 \mathrm{ml}$ & Bolus & $\begin{array}{l}\text { vector well tolerated. GFP expression was detected in most non-CNS tissues, including liver and muscle, } \\
\text { kidney, pancreas, heart, spleen, and pituitary. very low transduction was observed the frontal cortex and } \\
\text { spinal cord and hippocampus and cerebellum but transduction in DRG. Good tolerance of the virus }\end{array}$ & 45 \\
\hline IDUA & IV & NHP & adult & 2 & AAVPHP.B & $2.5 .10^{13} \mathrm{vg} / \mathrm{kg} 7.5 \cdot 10^{13} \mathrm{vg} / \mathrm{kg}$ & $1 \mathrm{ml}$ & Bolus & $\begin{array}{l}\text { vector well tolerated. GFP expression was detected in most non-CNS tissues, including liver and muscle, } \\
\text { kidney, pancreas, heart, spleen, and pituitary equivalent to AAV9 except for in skeletal muscle, where } \\
\text { transduction was higher for PHP.B vector well tolerated. Immune response against the virus }\end{array}$ & 45 \\
\hline eGFP & IV & NHP & & 1 & ssAAVg & $2.10^{13} \mathrm{vg} / \mathrm{kg}$ & & & $\begin{array}{l}\text { vector distribution to the CNS was substantially lower than that achieved at four- to eightfold lower doses } \\
\qquad \text { via CM }\end{array}$ & 88 \\
\hline
\end{tabular}

\begin{tabular}{|c|c|c|c|c|c|c|c|c|c|}
\hline $\begin{array}{l}\text { Transgene / } \\
\text { Pathology }\end{array}$ & Target & Age & Number & $\begin{array}{l}\text { Vector / } \\
\text { Buffer }\end{array}$ & Dose & Volume & Speed & Identification of the trial and results if available & Article \\
\hline CLN6/ Batten & IT & & 13 & AAVg & $1.5 .10^{13} \mathrm{vg}$ & & & NCT02725580, Phase I/II & NA \\
\hline $\begin{array}{l}\text { JeT-GAN / Giant } \\
\text { Axonal } \\
\text { Neuropathy }\end{array}$ & IT & & & AAV9 & & & & NCT02362438 & 206 \\
\hline NAGLU / MPSIIIB & & & & scAAV9 & & & & & NA \\
\hline SGSH / MPSIIIA & IV & & 9 ? & $\mathrm{AAV} s \mathrm{sc}$ & $\begin{array}{l}5.10^{12} \mathrm{vg} / \mathrm{kg}(\mathrm{n}=3) \text { and } \\
1.10^{13} \mathrm{vg} / \mathrm{kg}(\mathrm{n}=1)\end{array}$ & & & NCT02716246, Phase I/II & NA \\
\hline $\begin{array}{l}\text { SMN type } 1 / \\
\text { SMA }\end{array}$ & IV & child & $\begin{array}{l}15 \text { (cohort } 1 n=3 \text {, } \\
\text { cohort } 2 n=12 \text { ) }\end{array}$ & AAV9 & $\begin{array}{c}6.7 .10^{13} \mathrm{vg} / \mathrm{kg} \text { cohort } 1 \text { and } \\
2.10^{14} \mathrm{vg} / \mathrm{kg} \text { cohort } 2\end{array}$ & & & NCT02122952, Phase 1/II , longer survival, motor improvement & 41 \\
\hline SMN & IV & child & 6 & AAV9 & & & & NCT03837184, Phase III & NA \\
\hline SGSH / MPSIIIA & IV & & 12 & scAAV9 & $3.10^{13} \mathrm{vg} / \mathrm{kg}$ & & & NCT04088734 & NA \\
\hline $\begin{array}{l}\text { GLB1 / GM1 type } \\
\text { I and II }\end{array}$ & IV & $\begin{array}{c}6 \text { months }-1 \\
\text { year for GM1 } 1 \\
\text { type I and 2- } \\
12 \text { for GM1 } \\
\text { type II }\end{array}$ & 45 & AAVg & 1.5 to $4.5 .10^{13} \mathrm{vg} / \mathrm{kg}$ & & & NCT03952637 & NA \\
\hline hTERT/AD & IV /IT & $\begin{array}{l}45 \text { years and } \\
\text { older }\end{array}$ & 5 & & & & & NCT04133454 & NA \\
\hline $\begin{array}{l}\text { HEXA / HEXB Tay } \\
\text { sachs }\end{array}$ & IT & $\begin{array}{l}7 \text { and } 30 \\
\text { months old }\end{array}$ & 2 & AAVrh8 & $\begin{array}{l}\text { HEXA vector }(0.5 \mathrm{~mL}, 9.9 . \\
\left.10^{12} \mathrm{vg} / \mathrm{mL}\right) \text { mixed with } \\
\text { HEXB }\left(0.413 \mathrm{~mL}, 1.2 .10^{13}\right.\end{array}$ & $12 \mathrm{ml}$ & $1 \mathrm{ml} / \mathrm{min}$ & & 203 \\
\hline
\end{tabular}




\begin{tabular}{|c|c|c|c|c|c|c|c|c|}
\hline & & & & $\begin{array}{c}\text { vg/mL) to generate a 1:1 } \\
\text { equimolar formulation }\end{array}$ & & & NA \\
\hline GBA / Parkinson & ICM & $\begin{array}{c}40 \text { to } 75 \\
\text { years }\end{array}$ & 16 & & Low and high dose & & NCT04127578 \\
\hline $\begin{array}{c}\text { GRN / Fronto } \\
\text { temporal } \\
\text { dementia }\end{array}$ & ICM & $\begin{array}{c}30 \text { to } 80 \\
\text { years }\end{array}$ & 15 & Now, medium and high dose & NCT04408625 \\
\hline IDUA / MPS1 & ICM & $\begin{array}{c}4 \text { months } \\
\text { and older }\end{array}$ & 5 & AAV9 & 1 and $5.10^{10} \mathrm{gc} / \mathrm{kg}$ & & & NCT03580083 \\
\hline IDS / MPS2 & ICM & $\begin{array}{c}4 \text { months to } \\
5 \text { years }\end{array}$ & 6 & AAV9 & 1.3 and $6.5 .10^{10} \mathrm{gc} / \mathrm{kg}$ & & & \\
\hline CLN3 & IT & children & 7 & scAAV9 & Low or high dose & & & NCT03566043 \\
\hline
\end{tabular}

\section{Table 6 : Clinical trials with Intra parenchymal administration}

\begin{tabular}{|c|c|c|c|c|c|c|c|c|c|}
\hline $\begin{array}{l}\text { Transgene / } \\
\text { Pathology }\end{array}$ & Target & Age & Number & $\begin{array}{l}\text { Vector / } \\
\text { Buffer }\end{array}$ & Dose & Volume & Speed & Identification of the trial and results if available & Article \\
\hline AADC/ParkD & Striatum & adult & & AAV2 & & & & NCT00229736, Increased risk of intracranial hemorrhage, Phase I motor improvement & 207 \\
\hline TPP-1/LINCL & 12 sites in WM & Children & & AAV2 & & & & Unsufficient but suggestion of slowing progression of disease & 207 \\
\hline $\begin{array}{l}\text { NTN (CERE-120) } \\
\text { /Parkinson }\end{array}$ & Putamen & & 12 & AAV2 & $\begin{array}{l}1.4 .10^{11} \mathrm{vg} / \mathrm{mL} \text { and } \\
5.7 .10^{11} \mathrm{vg} / \mathrm{mL}\end{array}$ & $40 \mu \mathrm{l}$ & & well tolerated, significant motor score improvement 6 months after infusion & 208 \\
\hline $\begin{array}{l}\text { NTN (CERE-120) } \\
\text { /Parkinson }\end{array}$ & Putamen & $\begin{array}{c}\text { Adult } \\
35-75 \text { years }\end{array}$ & $\begin{array}{c}38 / 20 \\
\text { sham }\end{array}$ & AAV2 & 5.7.10 $10^{11} \mathrm{vg} / \mathrm{mL}$ & $\begin{array}{c}40 \mu \mathrm{ll} / \\
\text { hemisphere }\end{array}$ & & $\begin{array}{l}\text { NCTO0252850, CERE } 120 \text {, double blinded clinical trial, afetr } 1 \text { year : } 13 / 38,4 / 20 \text { sham reacted } \\
\text { adversely to the injection, no clinically significant improvement versus placebo at } 12 \text { months }\end{array}$ & 208 \\
\hline $\begin{array}{l}\text { NTN (CERE-120) / } \\
\text { Parkinson }\end{array}$ & $\begin{array}{l}\text { Putamen + Subst } \\
\text { Nigra, bilateral }\end{array}$ & $\begin{array}{l}\text { Adult } 35-70 \\
\text { years }\end{array}$ & 60 & AAV2 & $2.4 .10^{12} \mathrm{vg}$ & & & NCT00985517, Phase I, double blinded, safely tolerated, 5 years f-up, no significant improvement & 208 \\
\hline AADC / Parkinson & Putamen & & 10 & AAV2 & $9.10^{10} \mathrm{vg}$ and $3.10^{11} \mathrm{vg}$ & & & $\begin{array}{l}\text { Low and high vector dose, well tolerated, dose dependent improvement in domapine synthesis } \\
\text { Elevated PET signal persisted over } 4 \text { years in both groups }\end{array}$ & 208 \\
\hline Prosavin & Striatum & $\begin{array}{c}\text { Adult } \\
48-65 \text { years }\end{array}$ & 15 & $\begin{array}{l}\text { Lentiviral } \\
\text { EIAV }\end{array}$ & $1.9 .10^{7} ; 4.10^{7}$ and $1.10^{8} \mathrm{TU}$ & & & $\begin{array}{l}\text { NCT01856439, Phase I/II, safely tolerated, modest effects but patients with higher dose of Prosavin } \\
\text { required lower dose of dopamine (enhanced dopamine production ?) }\end{array}$ & 208 \\
\hline $\begin{array}{l}\text { NGF (CERE-110)/ } \\
\text { Alzheimer }\end{array}$ & & $\begin{array}{l}\text { Adult } 55-80 \\
\text { years }\end{array}$ & 49 & AAV2 & $2.10^{11} \mathrm{vg}$ & & & NCT00876863, Phase II, inefficient, safely tolerated & 209 \\
\hline CLN2 / Batten & ( $x 12$ by 6 bur holes) & Children & 10 & AAV2 & $2.5 .10^{12} \mathrm{vg}$ & $150 \mu \mathrm{l}$ & $2 \mu \mathrm{l} / \mathrm{min}$ & NCT00151216, Phase I, Radiographical changes in $65 \%$ of 60 injections sites & 209 \\
\hline $\begin{array}{c}\text { GAD65 and } \\
\text { GAD67 / } \\
\text { Parkinson }\end{array}$ & $\begin{array}{l}\text { SubThalamic } \\
\text { Nucleus (unilateral) }\end{array}$ & $\begin{array}{c}\text { Adult } \\
25-75 \text { years }\end{array}$ & 12 & AAV2 & $\begin{array}{l}1.10^{11} \mathrm{vg} / \mathrm{mL} ; 3.10^{11} \mathrm{vg} / \mathrm{mL} \\
\quad \text { and } 1.10^{12} \mathrm{vg} / \mathrm{mL}\end{array}$ & $50 \mu \mathrm{l}$ & & $\begin{array}{l}\text { NCT00195143, Phase I/II, safe; neuroimaging improvement, clinical improvement at } 12 \text { months post } \\
\text { infusion, decrease of STN activity }\end{array}$ & 209 \\
\hline $\begin{array}{l}\text { NTN (CERE-120) / } \\
\text { Parkinson }\end{array}$ & & & 58 & AAV2 & $5.4 .10^{11} \mathrm{vg}$ & & & NCT00400634, Phase II, not effective & 208 \\
\hline $\begin{array}{c}\text { GAD65 and } \\
\text { GAD67/ Parkinson }\end{array}$ & $\begin{array}{l}\text { SubThalamic } \\
\text { Nucleus }\end{array}$ & $\begin{array}{c}\text { Adult } \\
\text { 30-75 years }\end{array}$ & 44 & AAV2 & $1.10^{12} \mathrm{vg}$ & & & NCTO0643890, Phase II, well tolerated, improvement at 6 months (not greater than DBS) & 206 \\
\hline ASPA / Canavan & & & 21 & AAV2 & $1.10^{\circ} \mathrm{vg}$ & & & & 206 \\
\hline ASPA Canavan & $(\mathrm{X6})$ & $4-83$ years & 13 & AAV2 & $9.10 \mathrm{e} 11 \mathrm{vg}$ & & & Phase I/II, No longterm adverse event, slowing of disease & 206 \\
\hline
\end{tabular}




\begin{tabular}{|c|c|c|c|c|c|c|c|c|c|}
\hline CLN2/Batten & WM & & 16 & AAV rh.10 & $\begin{array}{l}9.10^{11} \mathrm{vg}(\mathrm{n}=6) \text { and } \\
2.85 .10^{11} \mathrm{vg}(\mathrm{n}=10)\end{array}$ & & & NCT01161576, Phase I/II & ? \\
\hline CLN2 / Batten & WM & & 8 & AAV rh.10 & $9.10^{11} \mathrm{vg}$ and $2.85 .10^{11} \mathrm{vg}$ & & & NCT01414985, Phase I/II & ? \\
\hline NAGLU / MPSIIIB & & $\begin{array}{l}\text { Child (20-53 } \\
\text { months) }\end{array}$ & 4 & rAAV2/5 & $4.10^{12} \mathrm{vg}$ & & & $\begin{array}{l}\text { ISRCTN19853672, Phase I/II, well tolerated, induced sustained enzyme production in the brain, best } \\
\text { results in the youngest patients }\end{array}$ & 210 \\
\hline AADC/ Parkinson & & & 5 & AAV2 & $9.10^{10} \mathrm{vg}$ & & & Phase I, Safely tolerated, modest improvement in motor coordination at 6 months (placebo effect ?) & 211 \\
\hline AADC/ Parkinson & & & 10 & AAV2 & $3.10^{11} \mathrm{vg}$ & & & Phase l, safe possibly effective & 212 \\
\hline $\begin{array}{l}\text { SHSH-IRES-SUMF1 } \\
\text { /MPSIIIA }\end{array}$ & 12 sites in WM & $\begin{array}{l}\text { Child (32-70 } \\
\text { months) }\end{array}$ & 4 & AAV rh.10 & 7.2.10 $10^{11} \mathrm{vg}$ & $60 \mu \mathrm{l}$ & $2 \mathrm{~h}$ & NCT01474343, good tolerance, possible but moderate clinical improvement, & 38 \\
\hline $\begin{array}{l}\text { AADC / AADC } \\
\text { deficiency }\end{array}$ & Putamen & $\begin{array}{l}\text { Child }(1.67- \\
8.42 \text { years })\end{array}$ & 10 & AAV2 & $1.81 .10^{11} \mathrm{vg}$ & $80 \mu \mathrm{l} /$ target & $3 \mu \mathrm{l} / \mathrm{min}$ & NCT01395641, Phase I/II, motor development improvement in children & 35 \\
\hline $\begin{array}{l}\text { AADC/AADC } \\
\text { deficiency }\end{array}$ & $\mathrm{SN}+\mathrm{VTA}$ & & & & & & & NCT02852213, Phase I & NA \\
\hline $\begin{array}{l}\text { CAG-NGF / } \\
\text { Alzheimer }\end{array}$ & $\begin{array}{l}\text { Nucleus Basalis } \\
\text { Meynert }\end{array}$ & $\begin{array}{c}\text { Adult } \\
50-80 \text { years }\end{array}$ & 10 & AAV2 & & & & NCT00087789, Phase I, Safe, biologically effective & 212 \\
\hline NGF / Alzheimer & & $\begin{array}{c}\text { Adult }>50 \\
\text { years }\end{array}$ & 8 & & & & & NCT00017940 & NA \\
\hline GDNF & putamen & adult & 12 & AAV2 & & & & NCT04167540/ Phase 1B & $\mathrm{NA}$ \\
\hline GDNF / Parkinson & $\begin{array}{l}\text { (x16, } 4 \text { in } \\
\text { cerebellum) }\end{array}$ & $\begin{array}{c}\text { Adult } \\
>18 \text { years }\end{array}$ & 24 & AAV2 & $\begin{array}{l}9.10^{10} \mathrm{vg} ; 3.10^{11} \mathrm{vg} ; \\
9.10^{11} \mathrm{vg} \text { and } 3.10^{12} \mathrm{vg}\end{array}$ & & & NCT01621581, Phase I & NA \\
\hline ARSA / MLD & 12 sites in WM & $\begin{array}{c}\text { Child } \\
6-60 \text { months }\end{array}$ & 4 & AAV rh.10 & $\begin{array}{l}1.10^{12} \mathrm{vg} / \mathrm{kg}(\mathrm{n}=2) \text { and } \\
4.10^{13} \mathrm{vg} / \mathrm{kg}(\mathrm{n}=2)\end{array}$ & $60 \mu \mathrm{l} /$ site & $\begin{array}{l}0,5 \mu \mathrm{l} \\
/ \mathrm{min}\end{array}$ & NCT01801709, Phase I/II & NA \\
\hline SGSH / MPS IIIA & 6 sites in WM & Child & 20 & AAVrh10 & & & & NCT03612869, Phase III & NA \\
\hline $\begin{array}{c}\text { miHTT/Huntingto } \\
n\end{array}$ & Intra striatal & adult & 26 & AAV5 & $6.10^{12} \mathrm{vg}$ and $6.10^{13} \mathrm{vg}$ & & & NCT04120493, Phase I/II & NA \\
\hline AADC & & $\begin{array}{l}\text { Adults } 40 \text { to } \\
75 \text { years }\end{array}$ & 42 & AAV2 & $2,5.10^{12} \mathrm{vg}$ & & & NCT03562494, Phase II & NA \\
\hline
\end{tabular}

Table 7 : Devices for intracerebral gene therapy delivery

\begin{tabular}{|c|c|c|c|c|c|}
\hline Intracerebral cathether & Developing team/company & & back flow reduction & design & Article \\
\hline Hamilton Syringe & Hamilton & rigid, steel & no & endport & \\
\hline UCSF « homemade» & UCSF, Medgenesis Therapeutics and Brainlab AG & $\begin{array}{l}\text { rigid, fused silica, then flexible } \\
\text { canna with rigid tip ; }\end{array}$ & stepped profile & end port, step design & 213 \\
\hline Smartflow & MRI Interventions, Inc / UCSF & $\begin{array}{l}\text { rigid, ceramic, fused silica liner } \\
\text { and a polymer sheath }\end{array}$ & stepped profile & endport, step design & 214 \\
\hline MEMS & Alycone,Inc, Cornell & microfrabricated silicon cannula & stepped profile & dual lumen, coupled to multiple proximal tubing & 215 \\
\hline Neuroinfuse & $\begin{array}{c}\text { Renishaw / Univ Bristol } \\
\text { Renishaw Medical Solutions, Neurological Applications Department, } \\
\text { New Mills, Wotton-Under-Edge, Gloucestershire GL12 8JR, UK } \\
\end{array}$ & carbothane & $\begin{array}{l}\text { stepped profile / recesses } \\
\text { stepped }\end{array}$ & Sub $1 \mathrm{~mm}$ diameter catheters and guide tubes & 216,217 \\
\hline gliasite / emory University & IsoRay / Emory University & inflatable & no & $\begin{array}{l}\text { balloon tipped, } 2,3 \text {, and } 4 \mathrm{~cm} \text { with corresponding full } \\
\text { volumes of } 5,15 \text { and } 35 \mathrm{cc} \text {. }\end{array}$ & 218 \\
\hline hollow fiber & Twin Star Medical & & & micro-porous & \\
\hline
\end{tabular}




\begin{tabular}{|c|c|c|c|c|c|}
\hline $\begin{array}{l}\text { Cleveland Multiport } \\
\text { Catheter }\end{array}$ & $\begin{array}{l}\text { Cleveland Clinic } \\
\text { Infuseon Therapeutics }\end{array}$ & rigid & yes & $\begin{array}{l}\text { Multichannel } \\
\end{array}$ & 212 \\
\hline $\begin{array}{c}\text { Custom Made.Bristol } \\
\text { University }\end{array}$ & Bristol University & rigid & No & One port & 219 \\
\hline $\begin{array}{l}\text { Barium - impregnated one } \\
\text { port infusion catheter }\end{array}$ & Vygon Valley Forge, PA, USA & & & one port & 212 \\
\hline $\begin{array}{l}\text { Barium - impregnated one } \\
\text { port infusion catheter }\end{array}$ & Medtronic & & barium impregnated & one port & 212 \\
\hline
\end{tabular}


